

\title{
NMR Study on the Possible Interactions Between Imidazolium Based Ionic Liquids and Extractants Widely Applied in Solvent Extraction and Separation of f-Ions
}

Vanya Kurteva, Maria Atanassova, Isabelle Billard

\section{To cite this version:}

Vanya Kurteva, Maria Atanassova, Isabelle Billard. NMR Study on the Possible Interactions Between Imidazolium Based Ionic Liquids and Extractants Widely Applied in Solvent Extraction and Separation of f-Ions. Journal of Solution Chemistry, 2015, 44 (12), pp.2416-2430. 10.1007/s10953015-0420-3 . hal-02271377

\section{HAL Id: hal-02271377 \\ https://hal.science/hal-02271377}

Submitted on 26 Aug 2019

HAL is a multi-disciplinary open access archive for the deposit and dissemination of scientific research documents, whether they are published or not. The documents may come from teaching and research institutions in France or abroad, or from public or private research centers.
L'archive ouverte pluridisciplinaire HAL, est destinée au dépôt et à la diffusion de documents scientifiques de niveau recherche, publiés ou non, émanant des établissements d'enseignement et de recherche français ou étrangers, des laboratoires publics ou privés. 


\section{Journal of Solution Chemistry}

\section{NMR study on the possible interactions between imidazolium based ionic liquids and widely applied in solvent extraction and separation of f-ions extractants

\author{
--Manuscript Draft--
}

\begin{tabular}{|c|c|}
\hline \multicolumn{2}{|l|}{ Manuscript Number: } \\
\hline Full Title: & $\begin{array}{l}\text { NMR study on the possible interactions between imidazolium based ionic liquids and } \\
\text { widely applied in solvent extraction and separation of f-ions extractants }\end{array}$ \\
\hline Article Type: & Original Research \\
\hline Keywords: & Ionic liquids * Chelating extractants * Neutral ligands * Interactions * NMR \\
\hline Corresponding Author: & $\begin{array}{l}\text { Vanya Kurteva } \\
\text { Bulgarian Academy of Sciences } \\
\text { Sofia, BULGARIA }\end{array}$ \\
\hline \multicolumn{2}{|l|}{$\begin{array}{l}\text { Corresponding Author Secondary } \\
\text { Information: }\end{array}$} \\
\hline Corresponding Author's Institution: & Bulgarian Academy of Sciences \\
\hline \multicolumn{2}{|l|}{$\begin{array}{l}\text { Corresponding Author's Secondary } \\
\text { Institution: }\end{array}$} \\
\hline First Author: & Vanya Kurteva \\
\hline \multicolumn{2}{|l|}{ First Author Secondary Information: } \\
\hline \multirow[t]{3}{*}{ Order of Authors: } & Vanya Kurteva \\
\hline & Maria Atanassova \\
\hline & Isabelle Billard \\
\hline \multicolumn{2}{|c|}{ Order of Authors Secondary Information: } \\
\hline \multicolumn{2}{|l|}{ Funding Information: } \\
\hline Abstract: & $\begin{array}{l}\text { A detailed NMR study on the possible interactions between a series of imidazolium } \\
\text { based ionic liquids ( } 1 \text {-alkyl-3-methylimidazolium bis(trifluoromethylsulfonyl)amide, } \\
\text { RmimTf2N, } \mathrm{n}=4,6,8,10) \text { and commonly applied in solvent extraction and separation } \\
\text { science of } 4 \mathrm{f} \text { and } 5 \mathrm{f} \text {-ions acidic chelating and neutral extractants is presented. } \\
\text { Analytical techniques applied are } 1 \mathrm{H}, 13 \mathrm{C}, 19 \mathrm{~F} \text { and } 31 \mathrm{P} \text { NMR spectra and NOESY } \\
\text { experiments. Investigation of the types and strengths of the solvent-solute interactions } \\
\text { is necessary for a knowledge-based features concerning chemical solubility, reactivity } \\
\text { and selectivity as ILs have a strong influence on the solvent extraction mechanism of } \\
\text { metallic species in comparison with traditional molecular solvents used. The goal of the } \\
\text { scientific research is to gain insight on the role of ILs as a perspective efficient "green" } \\
\text { medium in the solvent extraction processes with more pro-ecological aspect. } \\
\text { Experimental results do not evidence any specific interactions between the IL } \\
\text { components and the ligands. }\end{array}$ \\
\hline \multirow[t]{4}{*}{ Suggested Reviewers: } & $\begin{array}{l}\text { Ali Ouadi } \\
\text { CNRS, France } \\
\text { ali.ouadi@iphc.cnrs.fr } \\
\text { expert in the area of ionic liquids application }\end{array}$ \\
\hline & $\begin{array}{l}\text { Magdalena Bendova } \\
\text { E. Hala Laboratory of Separation Processes } \\
\text { bendova@icpf.cas.cz } \\
\text { expert in the area of ionic liquids application }\end{array}$ \\
\hline & $\begin{array}{l}\text { Mara Freire } \\
\text { University of Aveiro, Portugal } \\
\text { maragfreire@ua.pt } \\
\text { expert in the area of ionic liquids application }\end{array}$ \\
\hline & Milen Bogdanov \\
\hline
\end{tabular}


Sofia University

mbogdanov@chem.uni-sofia.bg

expert in the area of ionic liquids synthesis

Powered by Editorial Manager ${ }^{\circledR}$ and ProduXion Manager ${ }^{\circledR}$ from Aries Systems Corporation 
NMR study on the possible interactions between imidazolium based ionic liquids and widely applied in solvent extraction and separation of f-ions extractants

Vanya Kurteva ${ }^{\mathrm{a}, *} \cdot$ Maria Atanassova $^{\mathrm{b}, \mathrm{c}, \mathrm{d}} \cdot$ Isabelle Billard $^{\mathrm{b}, \mathrm{c}}$

\begin{abstract}
anstitute of Organic Chemistry with Centre of Phytochemistry, Bulgarian Academy of Sciences, Acad. G. Bonchev str., bl. 9, 1113 Sofia, Bulgaria

E-mail: vkurteva@orgchm.bas.bg; Phone: +359 2 9606156; Fax: +359 28700225

${ }^{\mathrm{b}}$ University of Grenoble Alpes, Grenoble, France

${ }^{\mathrm{c}} \mathrm{CNRS}$, LEPMI, UMR 5279, 1130 rue de la piscine, 38000 Grenoble, France

${ }^{\mathrm{d}}$ University of Chemical Technology and Metallurgy, Department of General and Inorganic Chemistry, 8 Kliment Ohridski blvd., 1756 Sofia, Bulgaria
\end{abstract}

\begin{abstract}
A detailed NMR study on the possible interactions between a series of imidazolium based ionic liquids (1-alkyl-3-methylimidazolium bis(trifluoromethylsulfonyl)amide, $\operatorname{RmimTf}_{2} \mathrm{~N}, \mathrm{n}=4,6$, $8,10)$ and commonly applied in solvent extraction and separation science of $4 \mathrm{f}$ and $5 \mathrm{f}$-ions acidic chelating and neutral extractants is presented. Analytical techniques applied are ${ }^{1} \mathrm{H},{ }^{13} \mathrm{C}$, ${ }^{19} \mathrm{~F}$ and ${ }^{31} \mathrm{P}$ NMR spectra and NOESY experiments. Investigation of the types and strengths of the solvent-solute interactions is necessary for a knowledge-based features concerning chemical solubility, reactivity and selectivity as ILs have a strong influence on the solvent extraction mechanism of metallic species in comparison with traditional molecular solvents used. The goal of the scientific research is to gain insight on the role of ILs as a perspective efficient "green" medium in the solvent extraction processes with more pro-ecological aspect. Experimental results do not evidence any specific interactions between the IL components and the ligands.
\end{abstract}

Key-words Ionic liquids $\bullet$ Chelating extractants $\bullet$ Neutral ligands $\bullet$ Interactions $\bullet$ NMR

\title{
1. Introduction
}

Ionic liquids (ILs) are a class of remarkable diluents with unusual solvation properties that consist entirely of ions. Today, ILs represent a key instrument of the green chemistry converting numerous processes in environmentally friendly procedures [1-2] with comprehensive industrial applications $[3,4]$ and undoubtedly unquestionable future in critical 
technological areas such as nuclear fuel cycles. The main advantages of ILs over molecular organic solvents are the unique ionic character, extremely wide liquid diapason (up to $800^{\circ} \mathrm{C}$ ), non-volatility, no vapour pressure, non-flammability, negligible toxicity but not always [5], capability to dissolve a wide spectrum of organic and inorganic compounds, an excellent solution behaviour, adjustable miscibility and polarity, multiple reusability etc. ILs can be used as design solvents or the so-called task specific ionic liquids, due to the ability to adjust their physicochemical properties in a variety of applications. Imidazolium based ILs are among the most widely applied in synthesis, catalysis, separation science and continue to attract increasing interest due to their low melting points and viscosity, no complicated synthesis, and good stability to oxidative/reductive conditions [6-11]. Their properties are strongly dependent on the length of the alkyl chain and on the anion component. Most often fluorinated anions are chosen in solvent extraction systems because of their hydrophobicity, low viscosity and low coordination ability. Some of them are not so "green" as diluents due to their degradation in the aqueous phase; for instance $\left[\mathrm{PF}_{6}\right]^{-}$is hydrolytically unstable: $\left[\mathrm{PF}_{6}\right]^{-}+4 \mathrm{H}_{2} \mathrm{O} \leftrightarrow 5 \mathrm{HF}+\mathrm{F}^{-}+$ $\mathrm{H}_{3} \mathrm{PO}_{4}$. So, the selection of the anion $\left(\mathrm{CF}_{3} \mathrm{SO}_{2}\right)_{2} \mathrm{~N}^{-}\left(\mathrm{Tf}_{2} \mathrm{~N}^{-}\right)$is preferable, although some loss to the aqueous phase also occurs by solubilisation [12]. In general, it can be summarized that imidazolium cations are responsible for the air-, water-, temperature-, and radiation-stability of ILs, while their hydrophobicity is controlled by the anions. These properties, among many others, make them so attractive for science, technology and engineering and their application in the separation technology can be considered as a "hot" research topic. ILs are the obvious replacements for currently used organic noxious molecular solvents in all developing areas of chemistry.

The interactions between anionic part of ILs and metal ions are widely studied mainly in respect for their solvation [10,13-15]. On the other hand, it has been found in the extraction of natural compounds [16-19] that the interactions between the extracted species and ILs are crucial for efficient processes. It has also been demonstrated [20] that the interactions between ILs and radicals play an important role in the radical reactions in ionic liquids. Therefore, two reasonable questions arise: Are the extractant/IL interactions important in metal extractions? Are the structural changes occurring during equilibrium process and how this will affect the deviation from the ideal mixing behaviour solvent-solute?

Recently, we found that the new synthesized complexing agent 3-methyl-1-phenyl-4-(4trifluoromethylbenzoyl)-pyrazol-5-one extracts efficiently $\mathrm{Ln}^{3+}$ ions in 1-butyl-3methylimidazolium bis(trifluoromethylsulfonyl)amide [21] and, using NMR experiments, that no interactions occur between IL and the pyrazolone compound, independently on the solvent nature (benzene, acetonitrile or chloroform). For that reason, we decided to extend this study 
towards a variety of acidic chelating agents and neutral oxygen-donor ligands and ILs as a first step to exploit the potential offered by such systems. It is worthwhile to mention that the wellknown principle "like-dissolves-like" cannot be attributed in these investigations as the IL diluent possesses different chemical nature (i.e. ionic) from the solute (extractant molecule, neutral). On the other hand, the mutual solubility in aqueous-ionic liquid biphasic systems by Q-NMR technique was investigated applying five ILs of the imidazolium family with hydrophobic anion $\left(\mathrm{CF}_{3} \mathrm{SO}_{2}\right)_{2} \mathrm{~N}^{-}$and chloride, nitrate and perchlorate-based aqueous phases [12]. An unavoidable and so intricate ionic exchange was established with remarkable solubility of IL's anion under some of the chemical conditions [12]. The aim of the current study is to examine the possible interactions between a homologous series of hydrophobic imidazolium based ILs and commonly applied in separation science of f-ions extractants in order to detect some changes in the organic IL phase that may occur upon ligand addition, which, to the best of our knowledge, has never been discussed in the literature, by solution NMR spectroscopy.

\section{Materials and methods}

The acidic chelating and neutral extractants (E) were purchased from Fluka and Chemos $\mathrm{GmbH}$, respectively, and were used without further purification (purity >98\%). The deuterochloroform is from Aldrich, 99.8 atom \% D. The ionic liquids were supplied by Solvionic (all with purity of $99.5 \%$, Toulouse, France) and were dried in vacuo prior to sample preparation following a previously published procedure [22]. The individual NMR spectra of ILs, E (0.1 M concentrations) and their mixture were recorded as $\mathrm{CDCl}_{3}$ solutions on Bruker Avance 500 at $20^{\circ} \mathrm{C}$ and ${ }^{19} \mathrm{~F}$ at $25^{\circ} \mathrm{C}$. Various ratio i.e. 4:1, 2:1 and 1:1 of IL-E mixtures were recorded as $0.1 \mathrm{M}$ IL and $0.025 \mathrm{M}, 0.05 \mathrm{M}$ and $0.1 \mathrm{M}$ concentration of E, respectively. The concentration $0.1 \mathrm{M}$ and 1:1 ratio of IL-E mixtures were applied for deriving NOESY spectra. The chemical shifts were quoted in ppm in $\delta$-values against tetramethylsilane (TMS) as an internal standard and against $\mathrm{CF}_{3} \mathrm{COOH}$ and $\mathrm{H}_{3} \mathrm{PO}_{4}$ as external standards in ${ }^{19} \mathrm{~F}$ and ${ }^{31} \mathrm{P}$ spectra, respectively. The coupling constants were calculated in $\mathrm{Hz}$. The spectra were processed with Topspin 2.1 program.

\section{Results}

Modern high-resolution NMR spectroscopy in neat ILs is not applicable in this particular study due to serious drawbacks as emphasized in a recent paper [23]. First, only the changes in the IL signals can be followed due to the absence of reference extractants spectra. Second, only a small part of the IL entities equal to the molar concentration of the extractant, can interact and 
if such moieties exist, their signals are commensurable with the noise. For that reason, the explicit and easy applicable way to examine the possible IL-E interactions is served by the solution NMR.

The interactions between four hydrophobic ILs and five commonly used in liquid-liquid extraction processes of f-ions ligands were studied by NMR spectra in $\mathrm{CDCl}_{3}$ solution. The latter was chosen due to the limited solubility of ILs in hydrocarbons combined with the already observed by us fact [21] that the spectra of 4-trifluoromethylbenzoyl pyrazolone/bmimTf ${ }_{2} \mathrm{~N}$ mixture in benzene, acetonitrile and chloroform showed identical results; no interactions between the two species dissolved. The selected ILs of 1-alkyl-3methylimidazolium bis(trifluoromethylsulfonyl)amide group differing in their miscibility with water are 1-butyl- $\left(\operatorname{bmim}_{\mathbf{f}} \mathbf{N}\right)$, 1-hexyl- $\left(\boldsymbol{h m i m T f _ { 2 }} \mathbf{N}\right)$, 1-octyl- $\left(\operatorname{omim}_{\mathbf{T}} \mathbf{f} \mathbf{N}\right)$, and 1-decyl$\left(\operatorname{dmimTf}_{2} \mathbf{N}\right)$ presented on Figure 1 . Furthermore, viscosity at $25^{\circ} \mathrm{C}$ increases continuously with the length of the alkyl chain bound at the nitrogen atom of the imidazolium ring (cP: $61.14 \div 104$, for comparison the viscosity of conventional VOCs diluents is about $1 \mathrm{cP}$ ).

Fig. 1 The chemical structures of ionic liquids and extractant molecules studied.

The ligands under study could be divided in two main groups: acidic and neutral. The first series consists of commonly applied in extraction processes $\beta$-dicarbonyl compounds: thenoyltrifluoroacetone (HTTA), 4-benzoyl-3-methyl-1-phenyl-pyrazol-5-one (HP) and 4benzoyl-3-phenyl-isoxazol-5-one (HPBI), drawn in their predominant keto-enol form in solution, Figure 1. The second group of neutral molecules includes two acetamides: N,Ndiisobutyl-2-(octyl(phenyl)phosphoryl)acetamide $\quad$ (CMPO) and 2,2'-oxybis(N,Ndioctylacetamide) (TODGA).

The spectra of acidic chelating extractants showed sharp and well defined signals compatible with pure keto-enol forms. As demonstrated for the typical $\beta$-diketone compound HTTA on Figure 2, the tautomeric $\mathrm{CH}$ appears as singlet at $6.48 \mathrm{ppm}$ in the proton spectrum and at 93.7 ppm in the carbon as quartet due to a coupling with the three fluorine atoms. No $\mathrm{CH}_{2}$ signals are registered both in proton and carbon spectra. The same pattern was observed for 4acylpyrazolone, HP, and isoxazolone molecule, HPBI.

Fig. $2{ }^{1} \mathrm{H}$ (a) and ${ }^{13} \mathrm{C}$ (b) spectra of HTTA in $\mathrm{CDCl}_{3}$.

The interactions between the chosen four ILs and the acidic chelating extractants were studied by proton, carbon and fluorine spectra in different molar ratios, i.e. IL:E 4:1, 2:1 and 1:1. The 
spectra of $\operatorname{dmimTf}_{2} \mathbf{N}$, HTTA and their mixtures are shown on Figure 3 and selected signals in the spectra of ILs, HTTA and all IL/HTTA mixtures are listed on Table 1. As it can be seen, proton, carbon and fluorine resonances as well as $\mathrm{J}_{\mathrm{CF}}$ coupling constants have practically the same values in the spectra of the individual compounds and in those of their mixtures. The same pattern was observed in all cases, which is an indication that no interactions between the ionic liquid and acidic extractant occur in chloroform solution independently on their proportions. Some of the original spectra are given in the Supplementary Material (Fig. 9-20).

Fig. 3 Spectra of $\operatorname{dmimTf}_{2} \mathbf{N}$ (blue), $\operatorname{dmimTf}_{2} \mathbf{N}:$ HTTA 4:1 (brown), $\operatorname{dmimTf}_{2} \mathbf{N}$ :HTTA 2:1 (green), dmimTf 2 N:HTTA 1:1 (red), and HTTA (violet): a) ${ }^{1} \mathrm{H}$; b) ${ }^{13} \mathrm{C}$; c) ${ }^{19} \mathrm{~F}$.

Table 1. Selected signals in the spectra of ILs, HTTA and IL/HTTA mixtures.

\begin{tabular}{|c|c|c|c|c|c|c|c|c|}
\hline & ${ }^{19} \mathrm{~F}-\mathrm{IL}$ & ${ }^{19} \mathrm{~F}-\mathrm{E}$ & $\mathrm{CH}, \mathrm{E}$ & $\begin{array}{c}C \mathrm{H}, \\
\mathrm{J}_{\mathrm{CF}}, \mathrm{E}\end{array}$ & $\begin{array}{c}C_{q}-\mathrm{OH} \\
\mathrm{E}\end{array}$ & $\begin{array}{l}C_{q}=\mathrm{O}, \\
\mathrm{J}_{\mathrm{CF}}, \mathrm{E}\end{array}$ & $C F_{3}, \mathrm{~J}_{\mathrm{CF}}, \mathrm{E}$ & $\begin{array}{c}C F_{3}, \mathrm{~J}_{\mathrm{CF}}, \\
\mathrm{IL}\end{array}$ \\
\hline $\begin{array}{c}\text { bmim } \\
\mathbf{T f}_{2} \mathbf{N}\end{array}$ & -80.06 & - & - & - & - & - & - & $\begin{array}{c}119.90 \\
320.2\end{array}$ \\
\hline $4: 1$ & -80.07 & -76.71 & 6.452 & $\begin{array}{c}93.70 \\
2.7\end{array}$ & 182.96 & $\begin{array}{c}171.27 \\
36.7\end{array}$ & $\begin{array}{c}117.73 \\
280.3\end{array}$ & $\begin{array}{l}119.90 \\
320.8\end{array}$ \\
\hline $2: 1$ & -80.09 & -76.71 & 6.451 & $\begin{array}{c}93.70 \\
2.7\end{array}$ & 182.93 & $\begin{array}{c}171.23 \\
36.5\end{array}$ & $\begin{array}{c}117.73 \\
280.3\end{array}$ & $\begin{array}{c}119.89 \\
320.6 \\
\end{array}$ \\
\hline 1:1 & -80.09 & -76.71 & 6.452 & $\begin{array}{c}93.69 \\
2.7\end{array}$ & 182.97 & $\begin{array}{c}171.24 \\
36.7\end{array}$ & $\begin{array}{c}117.73 \\
280.6\end{array}$ & $\begin{array}{l}119.89 \\
320.4\end{array}$ \\
\hline HTTA & - & -76.70 & 6.452 & $\begin{array}{c}93.70 \\
2.7\end{array}$ & 182.93 & $\begin{array}{c}171.32 \\
36.7\end{array}$ & $\begin{array}{c}117.79 \\
280.6\end{array}$ & - \\
\hline $\begin{array}{c}\text { hmim } \\
\mathbf{T f}_{2} \mathbf{N}\end{array}$ & -80.06 & - & - & - & - & - & - & $\begin{array}{c}119.89 \\
320.1 \\
\end{array}$ \\
\hline $4: 1$ & -80.07 & -76.71 & 6.452 & $\begin{array}{c}93.69 \\
2.7\end{array}$ & 182.97 & $\begin{array}{c}171.31 \\
36.7\end{array}$ & $\begin{array}{l}117.73 \\
280.3\end{array}$ & $\begin{array}{c}119.89 \\
320.1\end{array}$ \\
\hline $2: 1$ & -80.06 & -76.71 & 6.452 & $\begin{array}{c}93.69 \\
2.7\end{array}$ & 182.97 & $\begin{array}{c}171.24 \\
36.5\end{array}$ & $\begin{array}{c}117.73 \\
280.5\end{array}$ & $\begin{array}{c}119.89 \\
320.1\end{array}$ \\
\hline 1:1 & -80.08 & -76.72 & 6.451 & $\begin{array}{c}93.68 \\
2.7\end{array}$ & 182.98 & $\begin{array}{c}171.22 \\
36.7\end{array}$ & $\begin{array}{c}117.72 \\
280.6\end{array}$ & $\begin{array}{c}119.89 \\
320.2 \\
\end{array}$ \\
\hline HTTA & - & -76.70 & 6.452 & $\begin{array}{c}93.70 \\
2.7 \\
\end{array}$ & 182.93 & $\begin{array}{c}171.32 \\
36.7\end{array}$ & $\begin{array}{c}117.79 \\
280.6\end{array}$ & - \\
\hline $\begin{array}{c}\underset{\mathbf{T f}_{2} \mathbf{N}}{\operatorname{omim}} \\
.\end{array}$ & -80.04 & - & - & - & - & - & - & $\begin{array}{c}119.89 \\
320.1\end{array}$ \\
\hline $4: 1$ & -80.04 & -76.71 & 6.453 & $\begin{array}{c}93.69 \\
2.7\end{array}$ & 182.97 & $\begin{array}{c}171.26 \\
36.6\end{array}$ & $\begin{array}{l}117.72 \\
280.7\end{array}$ & $\begin{array}{c}119.89 \\
320.4\end{array}$ \\
\hline $2: 1$ & -80.05 & -76.71 & 6.452 & $\begin{array}{c}93.69 \\
2.7\end{array}$ & 182.97 & $\begin{array}{c}171.24 \\
36.6\end{array}$ & $\begin{array}{c}117.72 \\
280.4\end{array}$ & $\begin{array}{c}119.89 \\
320.3\end{array}$ \\
\hline 1:1 & -80.05 & -76.72 & 6.451 & $\begin{array}{c}93.68 \\
2.7\end{array}$ & 182.97 & $\begin{array}{c}171.23 \\
36.6\end{array}$ & $\begin{array}{c}117.73 \\
280.7\end{array}$ & $\begin{array}{c}119.89 \\
320.3\end{array}$ \\
\hline HTTA & - & -76.70 & 6.452 & $\begin{array}{c}93.70 \\
2.7\end{array}$ & 182.93 & $\begin{array}{c}171.32 \\
36.7\end{array}$ & $\begin{array}{c}117.79 \\
280.6\end{array}$ & - \\
\hline dmim & -80.03 & - & - & - & - & - & - & 119.89 \\
\hline
\end{tabular}




\begin{tabular}{|c|c|c|c|c|c|c|c|c|}
\hline $\mathbf{T f}_{2} \mathbf{N}$ & & & & & & & & 320.4 \\
\hline \multirow{2}{*}{$4: 1$} & \multirow{2}{*}{-80.03} & \multirow{2}{*}{-76.71} & \multirow{2}{*}{6.453} & 93.69 & \multirow{2}{*}{182.96} & 171.26 & 117.72 & 119.89 \\
\hline & & & & 2.7 & & 36.6 & 280.3 & 320.3 \\
\hline \multirow{2}{*}{$2: 1$} & \multirow{2}{*}{-80.04} & \multirow{2}{*}{-76.71} & \multirow{2}{*}{6.452} & 93.69 & \multirow{2}{*}{182.97} & 171.24 & 117.72 & 119.89 \\
\hline & & & & 2.7 & & 36.6 & 280.5 & 320.4 \\
\hline \multirow{2}{*}{$1: 1$} & \multirow{2}{*}{-80.04} & \multirow{2}{*}{-76.71} & \multirow{2}{*}{6.451} & 93.68 & \multirow{2}{*}{182.97} & 171.24 & 117.73 & 119.90 \\
\hline & & & & 2.7 & & 36.5 & 280.6 & 320.2 \\
\hline \multirow{2}{*}{ HTTA } & \multirow[b]{2}{*}{. } & \multirow{2}{*}{-76.70} & \multirow{2}{*}{6.452} & 93.70 & \multirow{2}{*}{182.93} & 171.32 & 117.79 & \\
\hline & & & & 2.7 & & 36.7 & 280.6 & \\
\hline
\end{tabular}

The possible interactions were additionally investigated by analyzing the cross peaks in NOESY experiments recorded for 1:1 IL/E mixtures in 0.1 M concentrations. As illustrated on the example of dmimTf 2 N/HTTA (Fig. 4), only intramolecular interactions are registered. Despite the relatively high concentration for such experiment, no intermolecular cross peaks were observed. The same pattern is valid for other systems including HP and HPBI as target compounds and butyl-, hexyl- octyl- and decyl forms of $\operatorname{RmimTf}_{2} \mathrm{~N}$.

Fig. 4 Partial ${ }^{1} \mathrm{H}-{ }^{1} \mathrm{H}$ NOESY spectrum of $\operatorname{dmimTf}_{2} \mathbf{N}$ :HTTA 1:1 mixture.

The two neutral ligands under study, CMPO and TODGA, showed the same model of behavior in the NMR spectra (SM, Fig. 21-29). No chemical shift changes were registered in the spectra upon mixing with ILs. As illustrated on the example of $\operatorname{dmim}_{\mathbf{T}} \mathbf{T} \mathbf{N} / \mathbf{C M P O}$ mixture (Fig. 5), both proton and carbon resonances are identical in the spectra of the individual compounds and their mixtures independently on the IL/E ratio. Even the changes in the signals, which have to be the most significantly influences in case of interactions, those neighbouring to IL's nitrogens and extractant's carbonyls, are negligible (Table 2).

Fig. 5 Spectra of $\operatorname{dmimTf}_{2} \mathbf{N}$ (blue), $\operatorname{dmimTf}_{2} \mathbf{N}$ :CMPO 4:1 (brown), $\operatorname{dmimTf}_{2} \mathbf{N}$ :CMPO 2:1 (green), dmimTf $2 \mathbf{N}$ :CMPO 1:1 (red), and CMPO (violet): a) ${ }^{1} \mathrm{H}$; b) ${ }^{13} \mathrm{C}$.

Table 2. Selected signals in the spectra of CMPO, ILs and IL:CMPO 1:1 mixtures.

\begin{tabular}{|c|c|c|c|c|c|c|}
\hline & ${ }^{31} \mathrm{P}-\mathrm{E}$ & ${ }^{19} \mathrm{~F}-\mathrm{IL}$ & $\mathrm{CH}_{3}-3, \mathrm{IL}$ & $\mathrm{CH}-2, \mathrm{IL}$ & $C_{q}=\mathrm{O}, \mathrm{J}_{\mathrm{CP}}, \mathrm{E}$ & $C \mathrm{~F}_{3}, \mathrm{~J}_{\mathrm{CF}}, \mathrm{IL}$ \\
\hline CMPO & 37.83 & - & - & 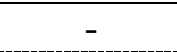 & $166.29,3.7$ & - \\
\hline 1:1 & 37.85 & -80.05 & 3.903 & 8.733 & $166.19,3.7$ & $119.87,321.1$ \\
\hline $\begin{array}{c}\text { bmim } \\
\mathbf{T f}_{2} \mathbf{N}\end{array}$ & - & -80.06 & 3.926 & 8.724 & - & $119.90,320.2$ \\
\hline $1: 1$ & 37.84 & -80.08 & 3.894 & 8.733 & $166.24,3.8$ & $119.88,320.6$ \\
\hline$\frac{\operatorname{Tf}_{2} \mathbf{N}}{\operatorname{hmim}}$ & - & -80.06 & 3.922 & 8.715 & - & $119.89,320.1$ \\
\hline 1:1 & 37.86 & -80.06 & 3.892 & 8.734 & $166.23,3.8$ & $119.83,321.1$ \\
\hline
\end{tabular}




\begin{tabular}{c|c|c|c|c|c|c}
$\mathbf{\text { omim }}$ & - & -80.04 & 3.924 & 8.719 & - & $119.89,320.1$ \\
$\mathbf{T} \mathbf{f}_{2} \mathbf{N}$ & - & -80.04 & 3.899 & 8.747 & $166.25,3.8$ & $119.87,321.3$ \\
\hline $\mathbf{1 : 1}$ & 37.84 & -80.3 & - & $119.89,320.4$ \\
$\mathbf{d m i m}$ & - & -80.03 & 3.926 & 8.723 & - \\
\hline $\mathbf{T f}_{2} \mathbf{N}$ & & &
\end{tabular}

The fluorine spectra (Fig. 6, Table 2) show that no changes in IL anion environment occur in the presence of the extractant. Both chemical shifts and carbon-fluorine constants possess practically the same values; 0.1-0.6 ppm and 0.5-0.9 Hz differences, respectively.

Fig. $6{ }^{19}$ F NMR spectra of $\operatorname{dmimTf}_{2} \mathbf{N}$ (blue), $\operatorname{dmimTf}_{2} \mathbf{N}$ :CMPO 1:1 (red), $\operatorname{dmimTf}_{2} \mathbf{N}$ :CMPO 2:1 (green), and $\operatorname{dmimTf}_{2} \mathbf{N}: \mathbf{C M P O} 4: 1$ (brown).

The ligand CMPO presents a special example in the series studied as it offers additional important technique to examine the interactions with ILs; phosphorus spectra, which are very sensitive to structural or conformational changes in general. As seen (Fig. 7, Table 2), phosphorus CMPO signals underwent negligible downfielding, 0.01-0.03 ppm, and carbonphosphorus constants remain practically the same in the spectra of $\mathbf{R m i m T f}_{2} \mathbf{N} / \mathbf{C M P O} 1: 1$ mixture in respect to that of the individual ligand.

Fig. $7{ }^{31} \mathrm{P}$ NMR spectra of CMPO (blue), $\operatorname{dmimTf_{2}N}$ :CMPO 4:1 (red), $\operatorname{dmimTf_{2}N:CMPO}$ 2:1 (green), and $\operatorname{dmim}_{\mathbf{T}} \mathbf{N} \mathbf{N}: \mathbf{C M P O} 1: 1$ (brown).

As in the case of the acidic extractants studied, no intermolecular interactions were detected in NOESY spectra of the IL/neutral ligand combinations. The latter is illustrated on Figure 8 on the example of $\operatorname{dmimTf}_{2} \mathbf{N}$ :CMPO 1:1 mixture.

Fig. 8 Partial ${ }^{1} \mathrm{H}^{-1} \mathrm{H}$ NOESY spectrum of $\operatorname{dmimTf}_{2} \mathbf{N}$ :CMPO 1:1 mixture.

\section{Discussion}

The unique solvation environments in the bulk of IL are the results of the forces exhibited by the $\mathrm{RmimTf}_{2} \mathrm{~N}$ on the solute including Coulomb, van der Waals and hydrogen bonding interactions $[24,25]$, which are already present to some degree in the pure ILs. The IL can act not only as a pure solvent and water scavenger $[12,25]$, but also as a reagent in particular by hydrogen bonding interaction of its anion and the organic molecules [25]. The strength of the 
ion-ion interaction depends on the IL structure and may strongly affect the ability of anions and/or cations to interact with dissolved species [26].

As already stressed above, molecular diluents and ILs display totally different structures and, therefore, offer very specific features for metal liquid/liquid extraction. ILs play a more active role not only in the partitioning process as a receiving phase but represent an important mode of metal ion extraction taking part in the formation of metallic species. It has been shown that aqueous/IL biphasic systems are significantly more complicated than that with VOCs and the presence of an acidic extractant as well as the length of the 1-alkyl chain of the IL cation, Rmim ${ }^{+}$, strongly influence mutual solubilities of all ions $\left(\mathrm{H}_{2} \mathrm{O}, \mathrm{H}^{+}, \mathrm{Rmim}^{+}\right.$and $\mathrm{Tf}_{2} \mathrm{~N}^{-}$, etc.) [27]. Addition of an acidic ligand to the IL phase has no significant effect onto the water solubility. The $\mathrm{p} K_{\text {alL }}$ values of ligands with different acidity HTTA, HP and HPBI have been measured in $\operatorname{bmimTf}_{2} \mathrm{~N}$ (pH range 1-3.5). The obtained three values of $\mathrm{p} K_{\mathrm{all}}$ corresponding to the ligand dissociation in a water saturated bmimTf ${ }_{2} \mathrm{~N}$ phase $(12200 \mathrm{ppm}$ average $\mathrm{H}_{2} \mathrm{O}$ amount) are very similar, 2.0-3.5, in comparison with the large difference observed for their $\mathrm{p} K_{\mathrm{aW}}$ values of 1.12-6.23 [27]. A clear effect of IL's nature is also observed during these measurements.

When considering the mechanism of lanthanoid(III) extraction towards IL or molecular solvent phases by use of $\beta$-dicarbonyl compounds, two very different situations can be found: in molecular solvents, the extracted species are always neutral, while in ILs, extracted species are predominantly charged, owing to the ionic nature of the solvent. In particular, the extraction of anionic complexes by HTTA has been shown to proceed by the exchange of the $\mathrm{Tf}_{2} \mathrm{~N}^{-}$anions into the aqueous phase:

$\mathrm{Ln}^{3+}{ }_{\mathrm{aq}}+4 \mathrm{HTTA}_{\mathrm{IL}}+\mathrm{bmim}^{+} \mathrm{Tf}_{2} \mathrm{~N}^{-}{ }_{\mathrm{IL}} \leftrightarrow \mathrm{bmim}^{+}\left[\mathrm{Ln}(\mathrm{TTA})_{4}\right]_{\mathrm{IL}}+4 \mathrm{H}_{\mathrm{aq}}^{+}+\mathrm{Tf}_{2} \mathrm{~N}^{-}{ }_{\mathrm{IL}}$

However, other mechanisms are possible, such as cationic exchange or extraction of neutral species, in a way rather similar to that occurring in molecular solvents [21]. In principle, the anionic exchange mechanism can be assessed by following the amount of $\mathrm{Tf}_{2} \mathrm{~N}^{-}$anions transferring to the aqueous phase during the extraction process but such a determination is difficult; even in the absence of metallic ions, some $\mathrm{Tf}_{2} \mathrm{~N}^{-}$anions transfer to the aqueous phase in amounts that are in the range of 2-70 $\mathrm{mM}$ depending on IL nature and aqueous phase composition $\left(\mathrm{Cl}^{-}, \mathrm{NO}_{3}{ }^{-}, \mathrm{ClO}_{4}^{-}\right)[12]$, while the amount of $\mathrm{Tf}_{2} \mathrm{~N}^{-}$transferred due to the extraction mechanism itself is in the order of the metallic ion concentration, which, most of the time, is very low as compared to the above mentioned $\mathrm{mM}$ range. Very efficient and simple way to determine the stoichiometry of the extracted species in the organic phase during liquid-liquid extraction is by use of the classical slope analysis method [28] but it is sometimes difficult to perform, either because it requests large solubility of the ligand or because slopes are quite 
often far from integer values in ILs, again because of the IL cation and anion solubilities in the aqueous phase, which sometimes distort the expected linear trends. This method gives good insight into the first coordination sphere of the metal ion in solvent extraction using molecular diluents. The method is based on an examination of the variation of the distribution ratio $(D)$ with the relevant experimental variables. A plot of the logarithm of $D$ vs the logarithm of one of the variables (the concentration of the two extractants and of $\mathrm{H}^{+}$), keeping the other two constant, indicates the stoichiometry of the extractable complex and a suitable equilibrium expression can be obtained, and consequently, the equilibrium constant can be computed [21, $29,30]$. The method will not give good results if some impurities are presented in the organic phase that is likely to form addition compounds with extractants. The antagonistic effect found for the extraction of $\mathrm{Pd}(\mathrm{II})$ with mixtures of 3-methyl-1-phenyl-4-propinoyl-pyrazol-5-one and a tertiary alkylamine, established by Zhang, was expressed by a decrease of the pyrazolone concentration in the organic phase $\left(\mathrm{CHCl}_{3}\right.$ medium $)$ due to the formation of an associated species HPMPP. $\mathrm{NR}_{1} \mathrm{R}_{2} \mathrm{R}_{3}$ through hydrogen bonding [31]. So, it is of great importance to investigate through the present NMR experiments, the interaction between some ligands and ILs, which could reduce the concentration of the free extractants; especially of co-extractant in synergistic solvent extraction usually used at lower concentration.

\section{Conclusion}

The possible interactions between a series of imidazolium based ionic liquids and acidic chelating and neutral extractants were studied by proton, carbon, fluorine, and phosphorus NMR spectra and it was shown that no interactions occurred in chloroform solution independently on the length of the imidazolium alkyl chain and on the structure and acidity of the ligand. NOESY technique provides valuable information and gives "insight" into the bulk liquid phase widely applied today as innovative medium in solvent extraction and separation chemistry. The absence of interactions, whatever the relative proportions of IL and ligand in chloroform is a strong indication that no interaction occurs in the bulk IL either. This could be a hint to explain the dramatic increase in extraction efficiencies observed for various ligands (among which those studied here) dissolved in IL media, as compared to organic molecular solvents.

\section{Acknowledgments}

The financial support by FP7-PEOPLE-Marie Curie Actions-IEF, project INNOVILLN (622906) 2014-2016, is gratefully acknowledged.

\section{Supplementary Material}


Supplementary material associated with this article can be found in the online version at .....

\section{References}

[1] Roger, R.D., Seddon, K.R. (eds.): Ionic Liquids as Green Solvents. Progress and Prospects, American Chemical Society. Washington, DC (2003).

[2] Kirchner, B. (ed.): Ionic Liquids. Springer-Verlag, Berlin, Heidelberg (2009).

[3] Rogers, R.D., Seddon, K.R. (eds.): Ionic Liquids: Industrial Applications for Green Chemistry. American Chemical Society, Washington, DC (2002).

[4] Plechkova, N.V., Seddon, K.R.: Applications of ionic liquids in the chemical industry. Chem. Soc. Rev. 37, 123-150 (2008).

[5] Kolarik, Z.: Ionic Liquids: How far do they extend the potential of solvent extraction of felements? Solvent Extr. Ion Exch. 31, 24-60 (2013).

[6] Wasserscheid, P., Welton, T. (eds.): Ionic Liquids in Synthesis. Wiley-VCH, Weinheim, Germany (2003).

[7] Rantwijk, F.V., Sheldon, R.A.: Biocatalysis in ionic liquids. Chem. Rev. 107, 2757-2785 (2007).

[8] Dietz, M.L.: Ionic liquids as extraction solvents: Where do we stand? Sep. Sci. Technol. 41, 2047-2063 (2006).

[9] Binnemans, K.: Lanthanides and actinides in ionic liquids. Chem. Rev. 107, 2592-2614 (2007).

[10] Billard, I.: Ionic liquids: New hopes for efficient lanthanide/actinide extraction and separation? In:. Bünzli, J.C.G, Pecharsky, V.K. (eds.) Handbook on the physics and chemistry of rare earths, Vol. 43, Chapter 256, pp. 213-273. Elsevier, New York (2013).

[11] Dzyuba, S.V., Bartsch, R.A.: Influence of structural variations in 1-alkyl(aralkyl)-3methylimidazolium hexafluorophosphates and bis(trifluoromethylsulfonyl)imides on physical properties of the ionic liquids. ChemPhysChem 3, 161-166 (2002).

[12] Atanassova, M., Mazan, V., Billard, I.: Modulating the solubilities of ionic liquid components in aqueous-ionic liquid biphasic systems: A Q-NMR investigation.

ChemPhysChem 16, 1703-1711 (2015).

[13] Billard, I., Gaillard, C.: Actinide and lanthanide speciation in imidazolium-based ionic liquids. Radiochim. Acta 97, 355-359 (2009).

[14] Gaillard, C., Azzi, A.E., Billard, I., Bolvin, H., Hennig, C.: Uranyl complexation in fluorinated acids $\left(\mathrm{HF}, \mathrm{HBF}_{4}, \mathrm{HPF}_{6}, \mathrm{HTf}_{2} \mathrm{~N}\right)$ : A combined experimental and theoretical study. Inorg. Chem. 44, 852-861 (2005). 
[15] Gaillard, C., Billard, I., Chaumont, A., Mekki, S., Ouadi, A., Denecke, M.A., Moutiers, G., Wipff, G.: Europium(III) and its halides in anhydrous room-temperature imidazoliumbased ionic liquids: A combined TRES, EXAFS, and molecular dynamics study. Inorg. Chem. 44, 8355-8367 (2005).

[16] Ferreira, R., Garcia, H., Sousa, A.F., Petkovic, M., Lamosa, P., Freire, C.S.R., Silvestre, A.J.D., Rebelo, L.P.N., Pereira, C.S.: Suberin isolation from cork using ionic liquids: characterisation of ensuing products. New J. Chem. 36, 2014-2024 (2012).

[17] Zirbs, R., Strassl, K., Gaertner, P., Schroder, C., Bica, K.: Exploring ionic liquid-biomass interactions: towards the improved isolation of shikimic acid from star anise pods. RSC Adv. 3, 26010-26016 (2013).

[18] Ribeiro, B.D., Coelho, M.A.Z., Rebelo, L.P.N., Marrucho, I.M.: Ionic liquids as additives for extraction of saponins and polyphenols from mate (Ilex paraguariensis) and Tea (Camellia sinensis). Ind. Eng. Chem. Res. 52, 12146-12153 (2013).

[19] Passos, H., Freire, M.G., Coutinho, J.A.P.: Ionic liquid solutions as extractive solvents for value-added compounds from biomass. Green Chem. 16, 4786-4815 (2014).

[20] Strehmel, V., Berdzinski, S., Rexhausen, H.: Interactions between ionic liquids and radicals. J. Mol. Liquids 192, 153-170 (2014).

[21] Atanassova, M., Kurteva, V., Lubenov, L., Billard, I.: Comparing extraction, synergism and separation of lanthanoids by use of acidic and neutral compounds in chloroform and one ionic liquid: Is the latter always “better”? RSC Adv. 4, 38820-38829 (2014).

[22] Billard, I., Georg, S.: Reactivity towards europium(III) of the radiolysis products of the ionic liquid 1-methyl-3-butyl-1H-imidazolium bis[(trifluoromethyl)sulfonyl]amide $\left(\mathrm{C}_{4}\right.$ $\operatorname{mimTf}_{2} \mathrm{~N}$ ) and effect of water: A TRLFS (Time-Resolved Laser-Induced Fluorescence Spectroscopy) preliminary study. Helv. Chim. Acta 92, 2227-2237 (2009).

[23] Giernoth, R., Bröhl, A., Brehm, M., Lingscheid, Y.: Interactions in ionic liquids probed by in situ NMR spectroscopy. J. Mol. Liquids 192, 55-58 (2014).

[24] Fumino, K., Ludwig, R.: Analyzing the interaction energies between cation and anion in ionic liquids: The subtle balance between Coulomb forces and hydrogen bonding. J. Mol. Liquids 192, 94-102 (2014).

[25] Stark, A.: Shaping micro- and macroscopic properties of ionic liquid-solute systems: Multi-functional task-specific agents. J. Mol. Liquids 192, 144-152 (2014).

[26] Khatun, S., Castner, Jr., E. W.: Ionic liquid-solute interactions studied by 2D NOE NMR spectroscopy. J. Chem. Phys. B (2015). doi: 10.1021/jp509861g.

[27] Atanassova, M., Billard, I.: Determination of $\mathrm{p} K_{\text {all }}$ values of three chelating extractants in ILs: Consequences for the extraction of 4 f elements. J. Solution Chem. 44, 606-620 (2015). 
[28] Marcus, Y., Kertes, A.S.: Synergistic extraction. In: Ion Exchange and solvent extraction of metal complexes, Chapter 11, pp. 815-858. Willey Interscience, New York (1969).

[29] Atanassova, M., Dukov, I.: A comparative study of the solvent extraction of the trivalent elements of the lanthanoid series with thenoyltrifluoroacetone and 4-benzoyl-3-methyl-1-

phenyl-2-pyrazolin-5-one using diphenylsulphoxide as synergistic agent. J. Solution Chem. 38, 289-301 (2009).

[30] Petrova, M.A., Dukov, I.: Effect of crown ethers on the solvent extraction and separation of lanthanide(III) ions with 4-benzoyl-3-methyl-1-phenyl-2-pyrazolin-5-one. Chem. Papers 62, 207-214 (2008).

[31] Zhang, A.: Study of the antagonistic extraction of palladium(II) with 1-phenyl-3-methyl4-propionylpyrazolone-5-one and an organic amine. Solvent Extr. Ion Exch. 19, 925-938 (2001). 


\section{Graphical Abstract}

1

2

3

4

5

6

7

8

9

10

11

12

13

14

15

16

17

18

19

20

21

22

23

24

25

26

27

28

29

30

31

32

33

34

35

36

37

38

39

40

41

42

43

44

45

46

47

48

49

50

51

52

53

54

55

56

57

58

59

60

61

62

63

64

65

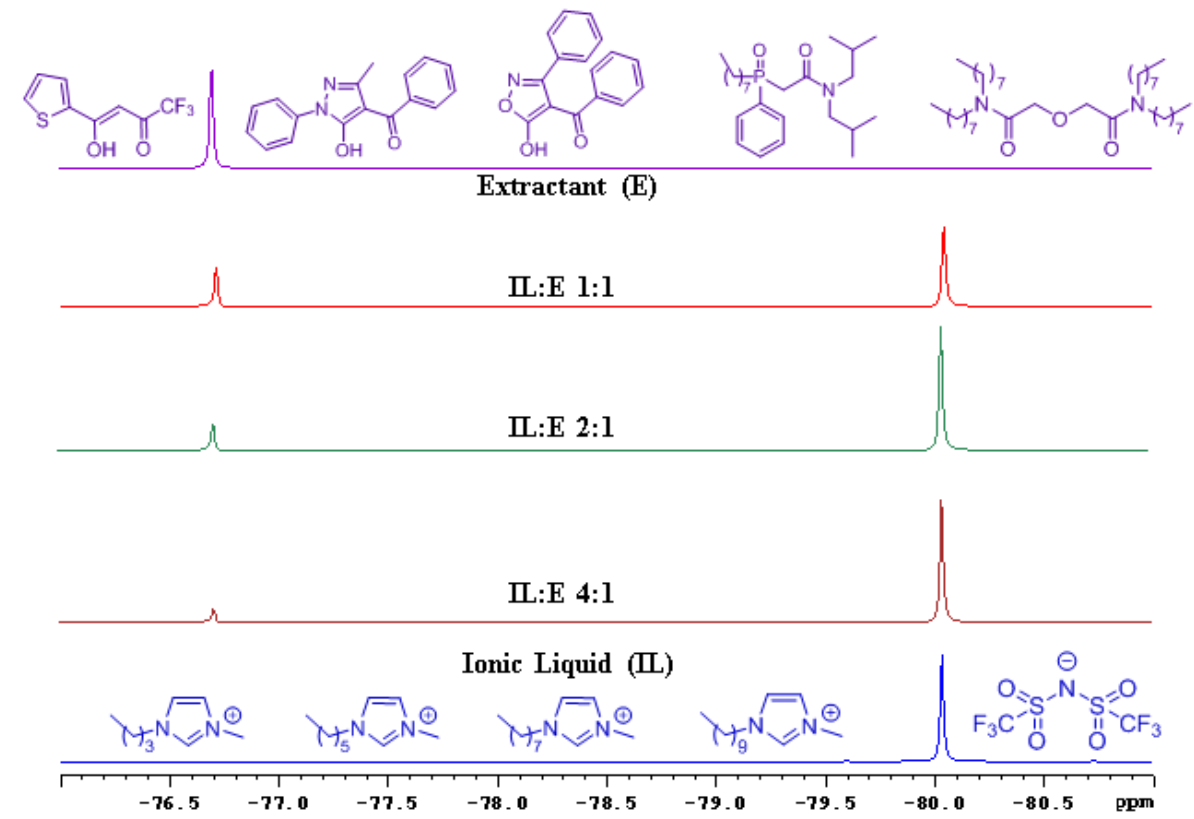




$$
\begin{aligned}
& \text { ILs }
\end{aligned}
$$



$$
\begin{aligned}
& \begin{array}{r}
R=\text { butyl, } \operatorname{bmimTf} \mathbf{N}_{2} \mathbf{N} \\
\text { hexyl, } \operatorname{hmimTf}_{2} \mathbf{N} \\
\text { octyl, omimTf }{ }_{2} \mathbf{N} \\
\text { decyl, dmimTf } \\
\mathbf{N} \mathbf{N}
\end{array}
\end{aligned}
$$

acidic extractants<smiles>O=C(/C=C(\O)c1cccs1)C(F)(F)F</smiles>

HTTA<smiles>Cc1nn(-c2ccccc2)c(O)c1C(=O)c1ccccc1</smiles>

HP<smiles>O=C(c1ccccc1)c1c(-c2ccccc2)noc1O</smiles>

HPBI<smiles>CCCCCCCCCN(CCCCCCCC)C(=O)COCC(=O)N(CCCCCCCC)CCCCCCCC</smiles>

Fig. 1

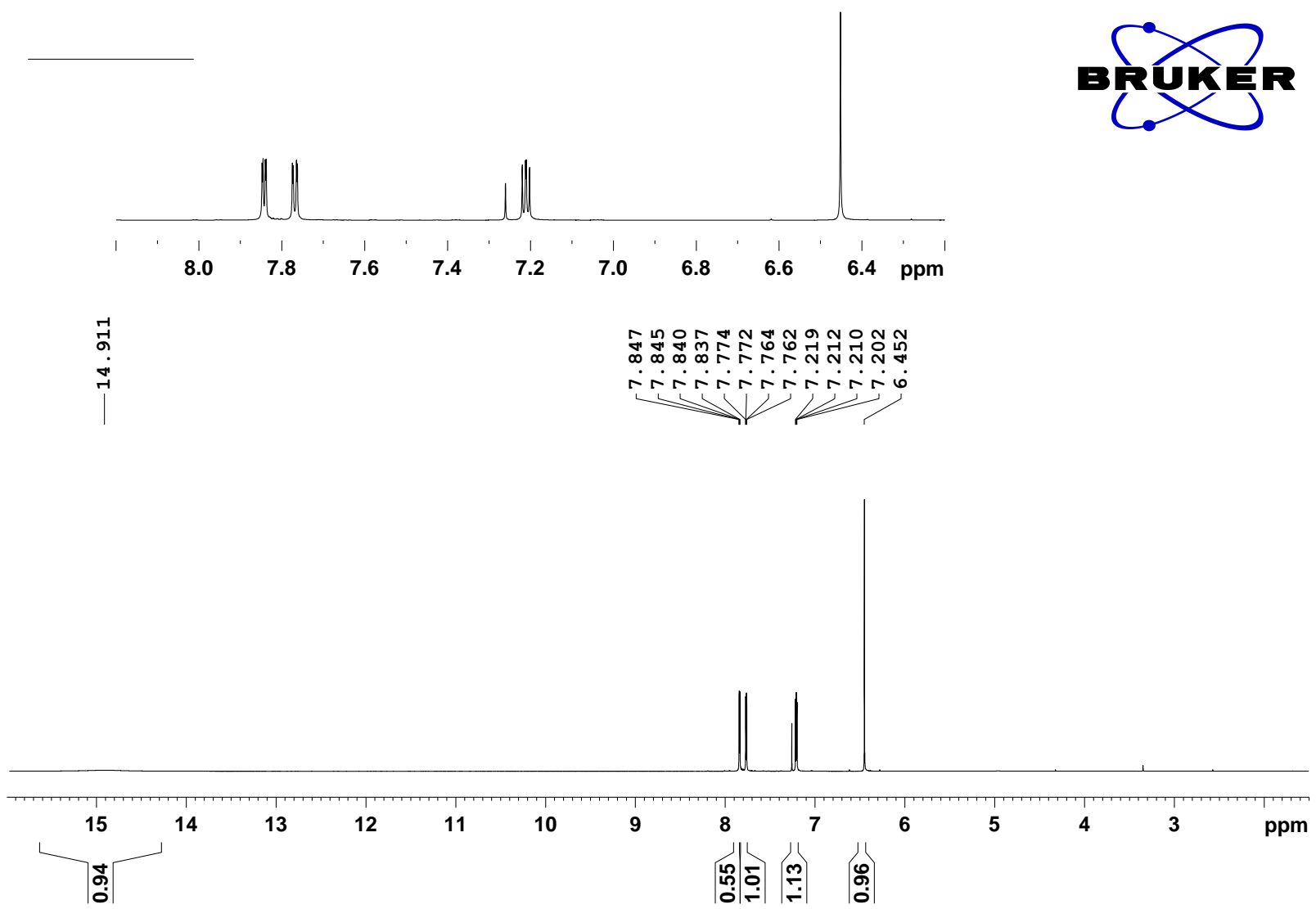

Fig 2a 


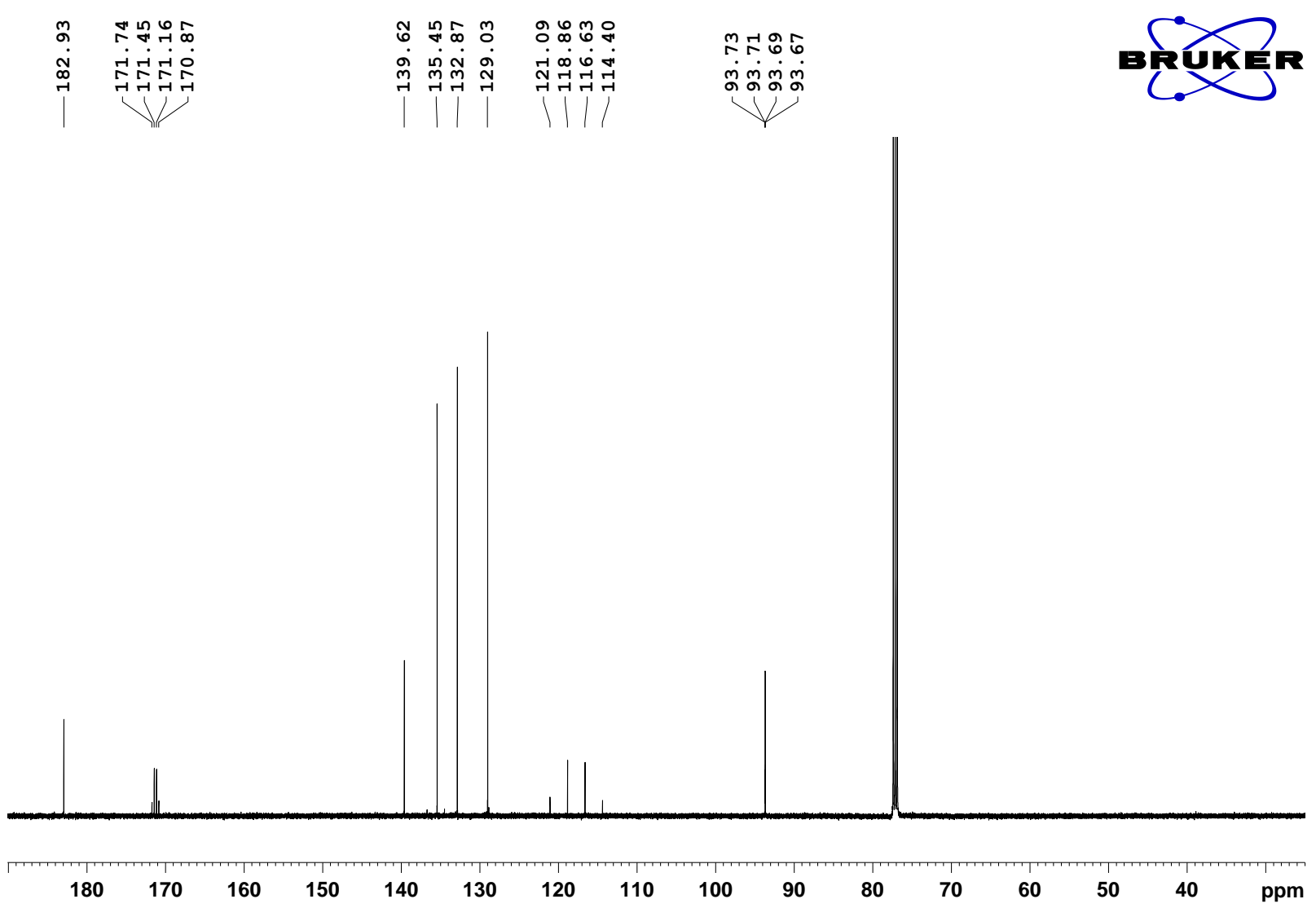

Fig 2b
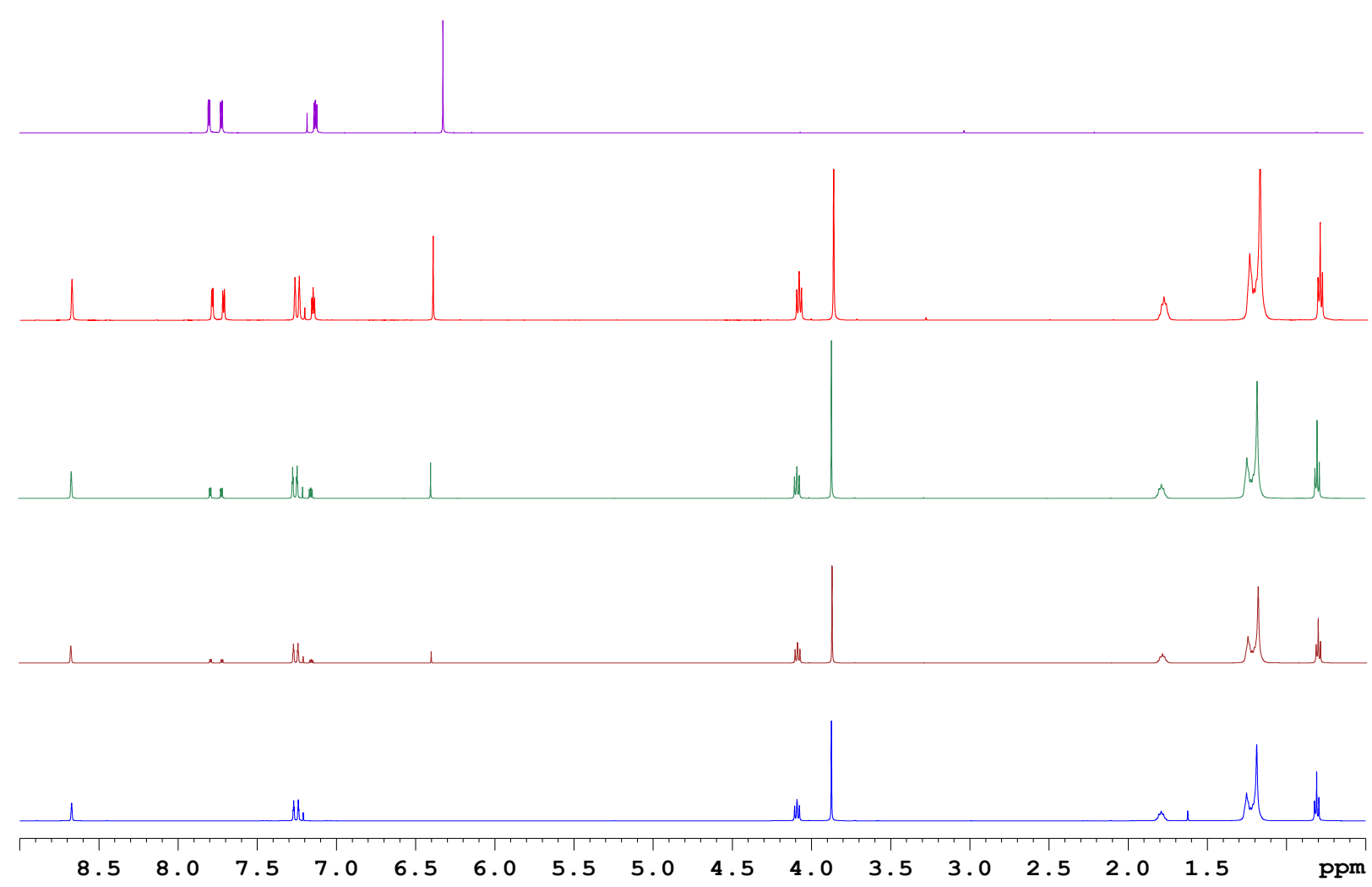

Fig 3a 


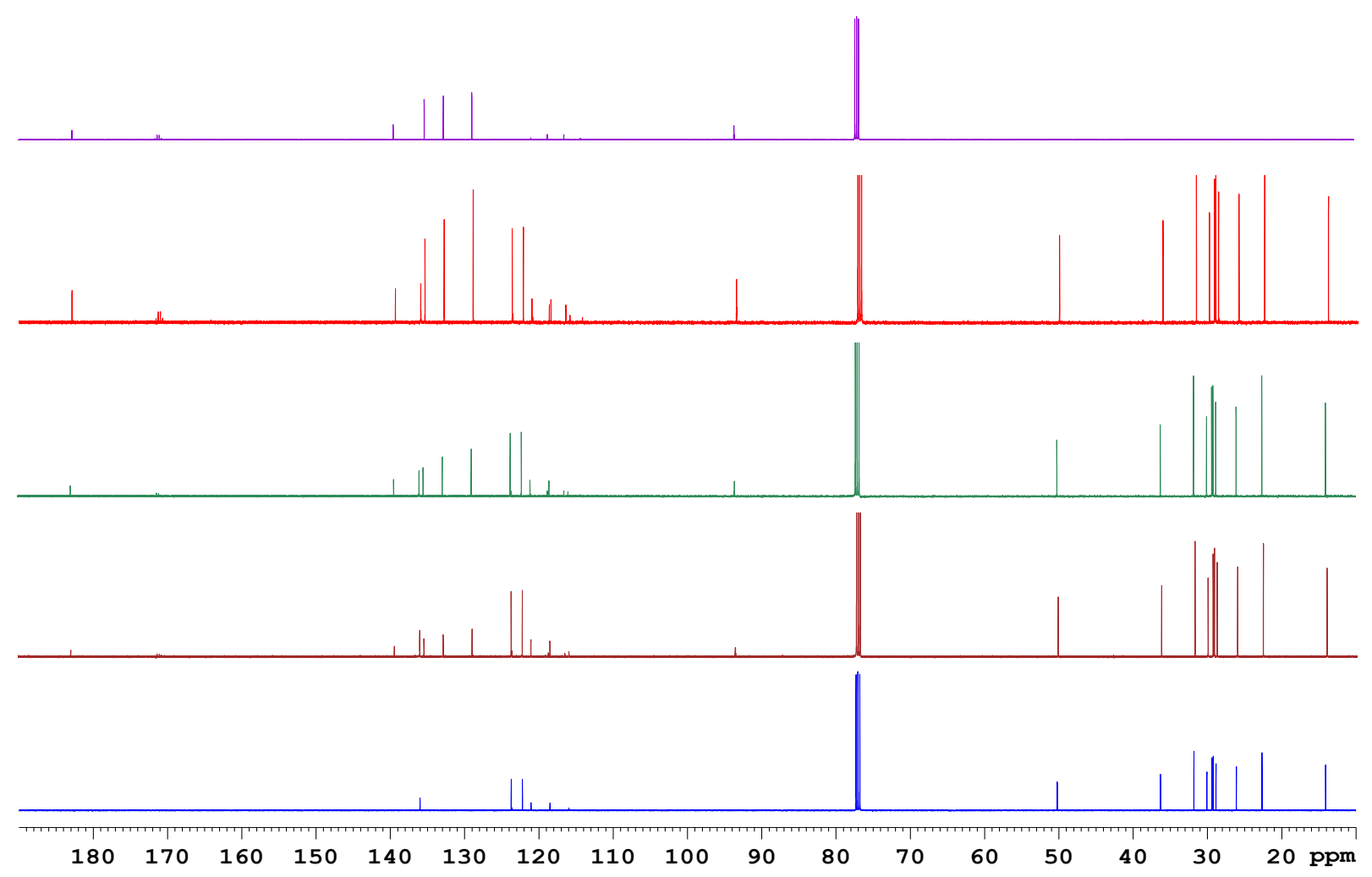

Fig 3b



Fig 3c 


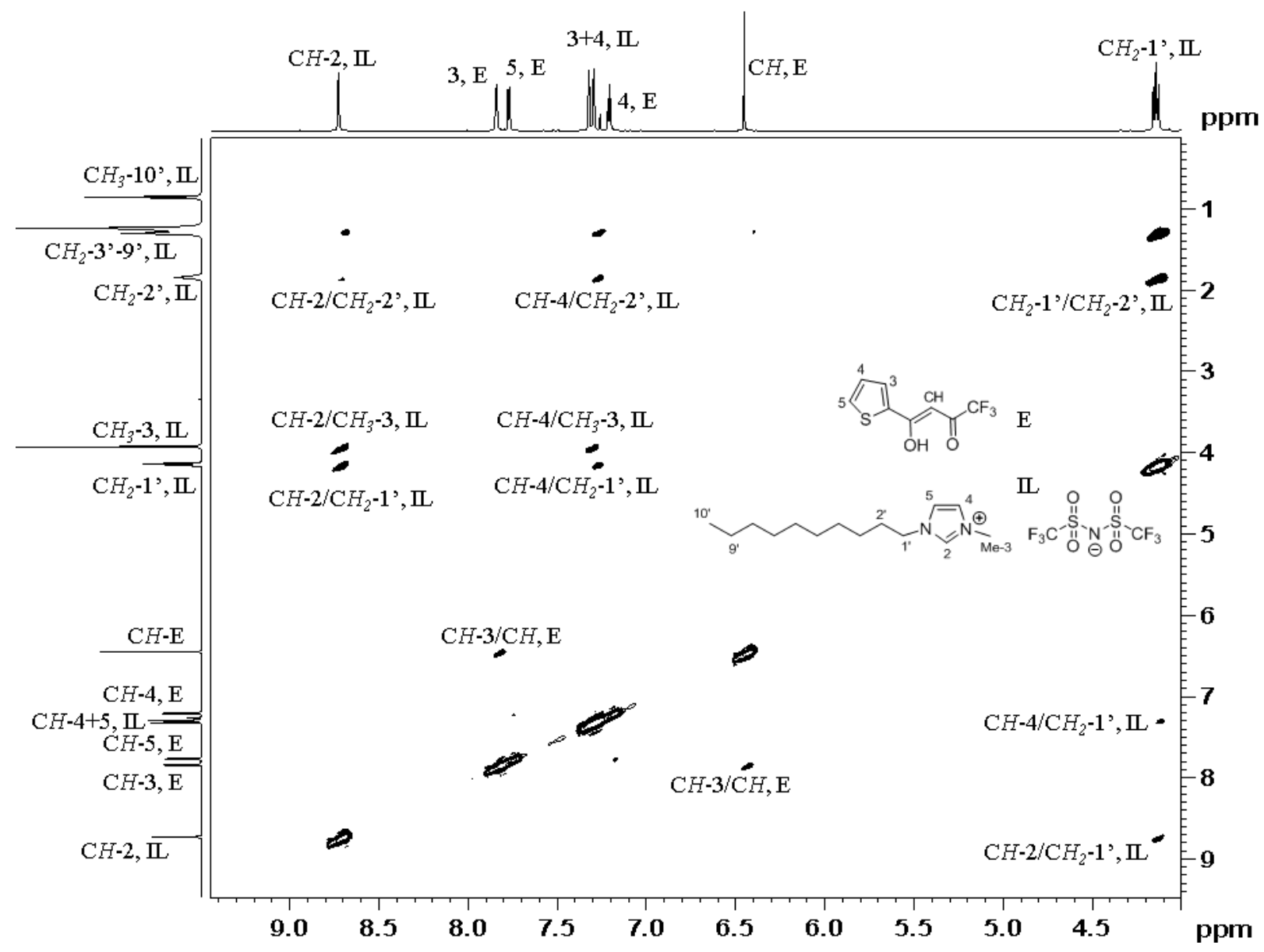

Fig 4


Fig 5a 


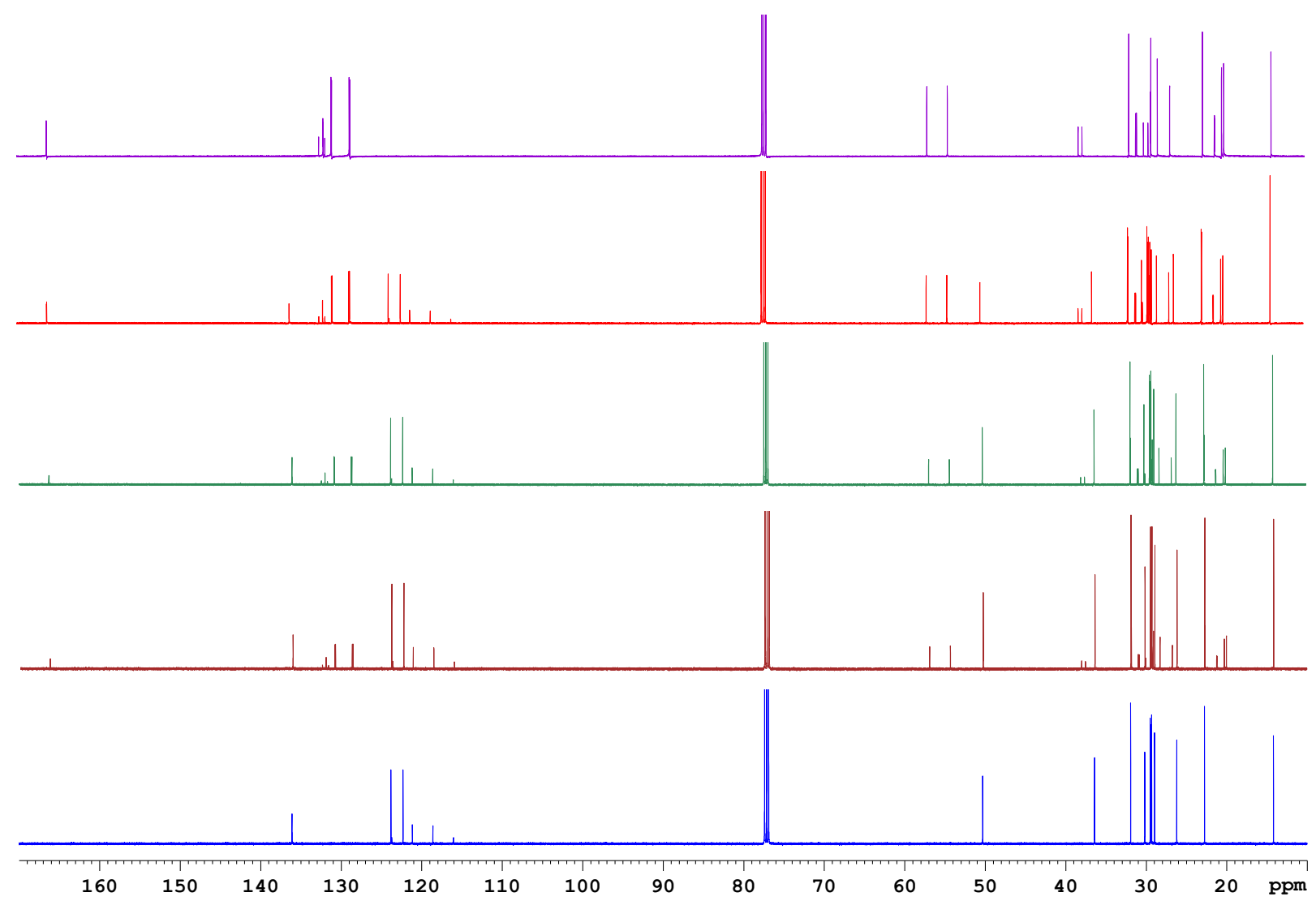

Fig 5b

mํํㅇ

$00^{\circ}$

$\infty \infty \infty$

I I

11

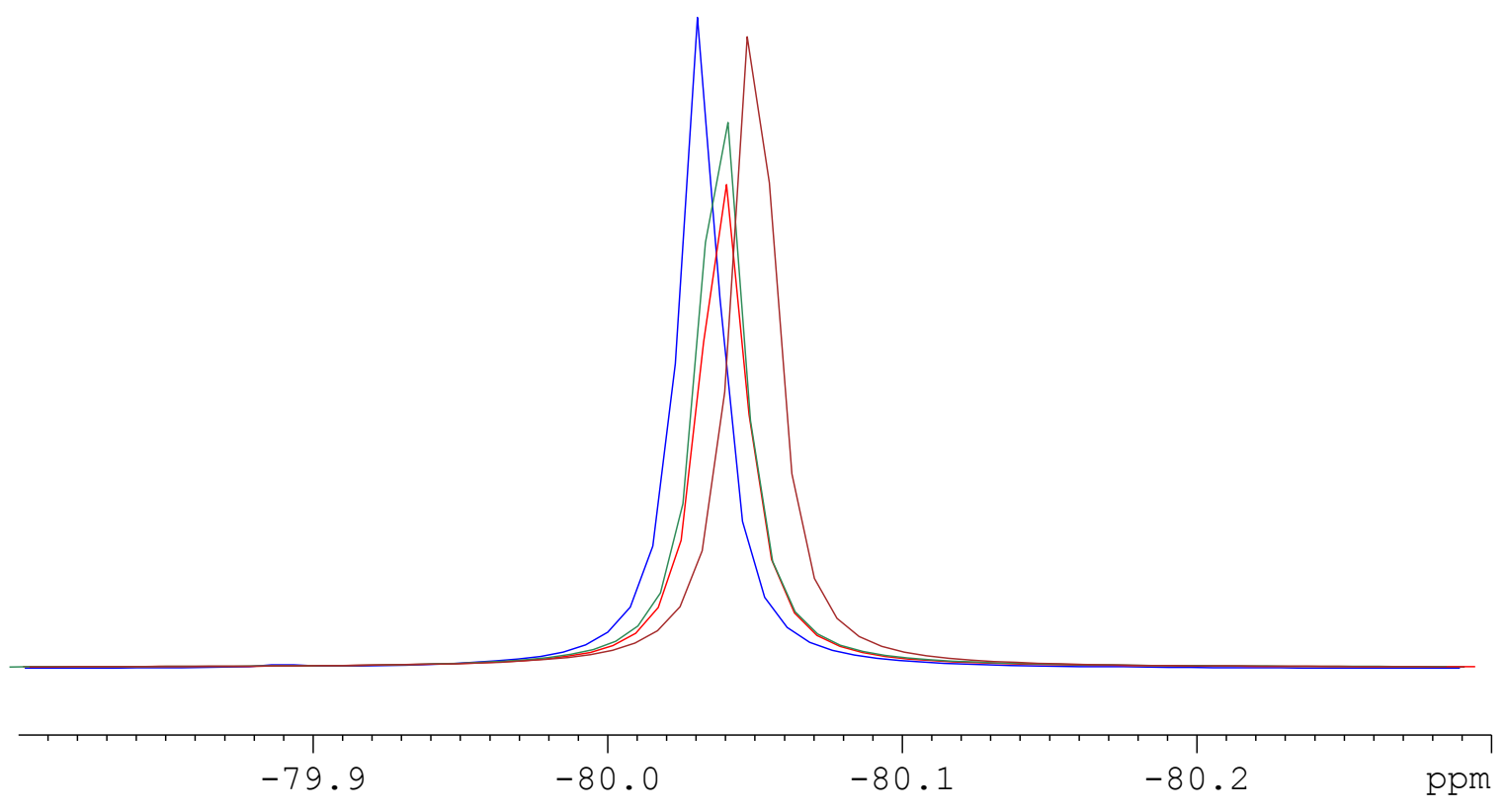

Fig 6 


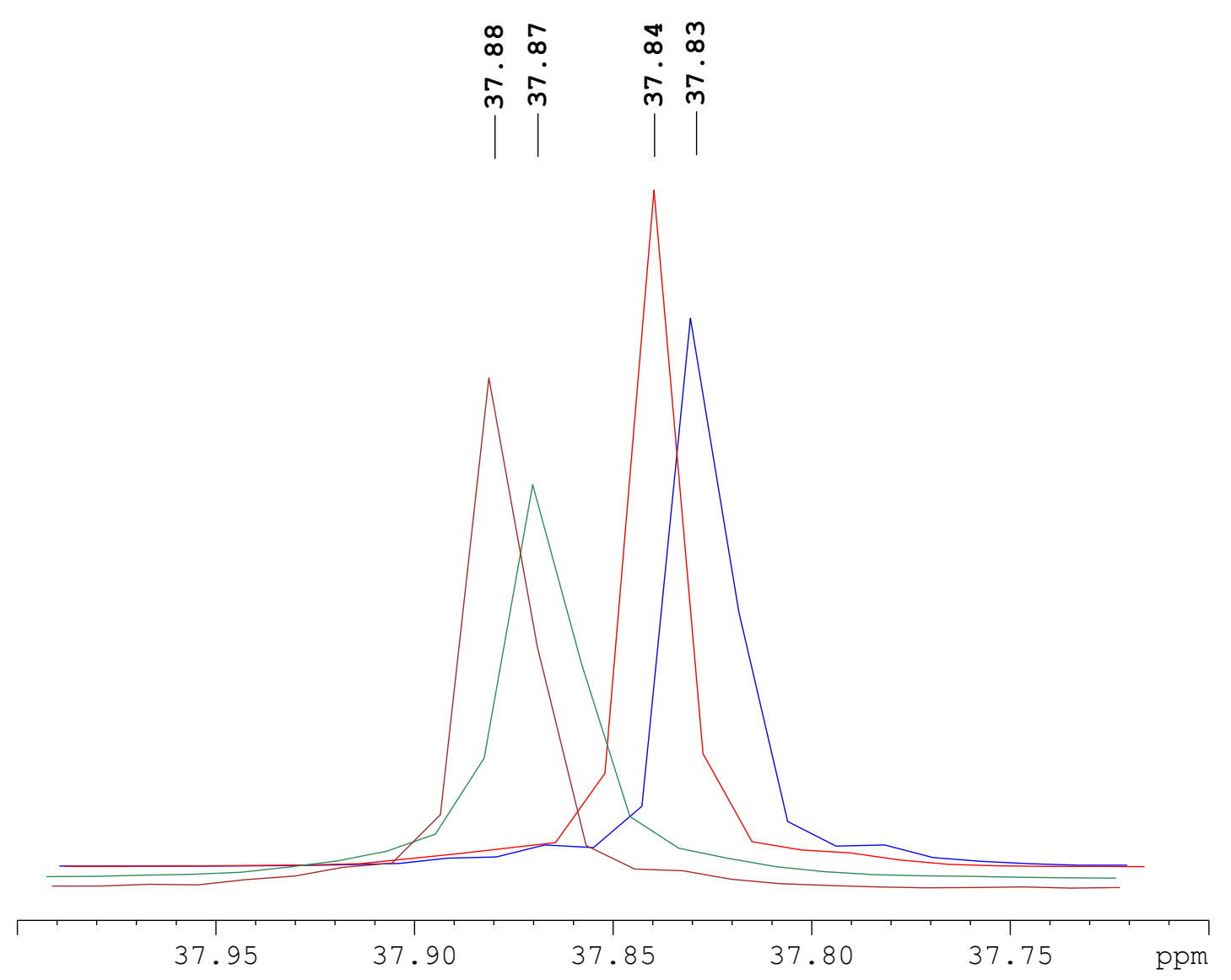

Fig 7

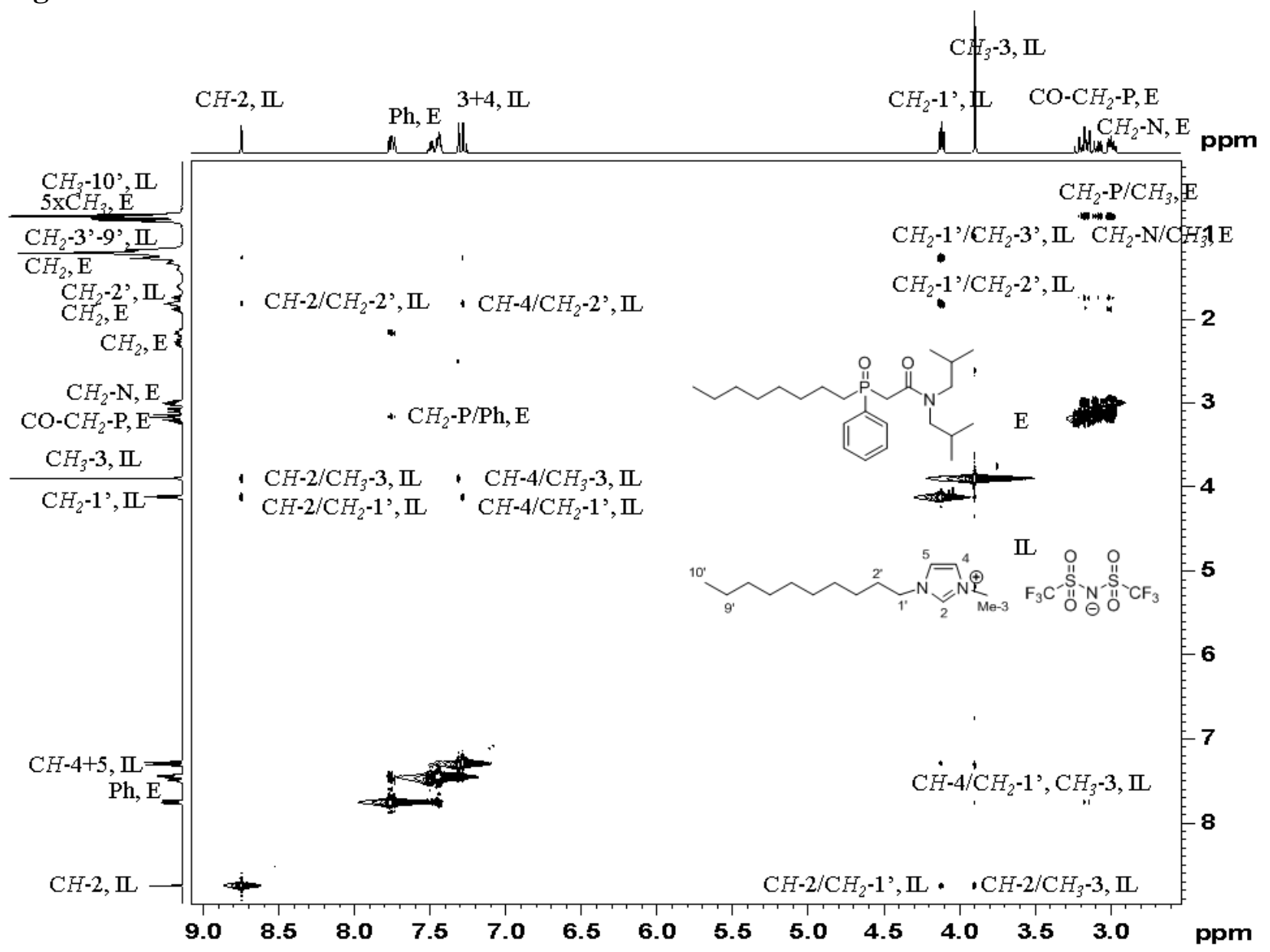

Fig 8 


\section{SUPPLEMENTARY MATERIAL}

\section{NMR study on the possible interactions between imidazolium based ionic liquids and widely applied in solvent extraction and separation of f-ions extractants}

$$
\text { Vanya Kurteva }{ }^{\mathrm{a}, *} \cdot \text { Maria Atanassova }{ }^{\mathrm{b}, \mathrm{c}, \mathrm{d}} \cdot \text { Isabelle Billard }^{\mathrm{b}, \mathrm{c}}
$$

anstitute of Organic Chemistry with Centre of Phytochemistry, Bulgarian Academy of Sciences, Acad. G. Bonchev str., bl. 9, 1113 Sofia, Bulgaria

E-mail: vkurteva@orgchm.bas.bg; Phone: +359 2 9606156; Fax: +359 28700225

${ }^{\mathrm{b} U n i v e r s i t y ~ o f ~ G r e n o b l e ~ A l p e s, ~ G r e n o b l e, ~ F r a n c e ~}$

${ }^{\mathrm{c} C N R S, ~ L E P M I, ~ U M R ~ 5279, ~} 1130$ rue de la piscine, 38000 Grenoble, France

${ }^{\mathrm{d} U n i v e r s i t y ~ o f ~ C h e m i c a l ~ T e c h n o l o g y ~ a n d ~ M e t a l l u r g y, ~ D e p a r t m e n t ~ o f ~ G e n e r a l ~ a n d ~ I n o r g a n i c ~}$ Chemistry, 8 Kliment Ohridski blvd., 1756 Sofia, Bulgaria

The NMR spectra of ILs, E and their mixture were recorded in $\mathrm{CDCl}_{3}$ on Bruker Avance 500 at $20^{\circ} \mathrm{C}$ and ${ }^{19} \mathrm{~F}$ at $25^{\circ} \mathrm{C}$. The signals were calibrated against tetramethylsilane (TMS) as an internal standard in ${ }^{1} \mathrm{H}$ and ${ }^{13} \mathrm{C}$ and against $\mathrm{CF}_{3} \mathrm{COOH}$ and $\mathrm{H}_{3} \mathrm{PO}_{4}$ as external standards in ${ }^{19} \mathrm{~F}$ and ${ }^{31} \mathrm{P}$ spectra, respectively. The spectra were processed with Topspin 2.1 program.

\section{Table of Contents}

\begin{tabular}{lcc}
\hline & Figures & Page \\
\hline I) NMR spectra of IL/HTTA mixtures & $9-12$ & 2 \\
II) NMR spectra of IL/HP mixtures & $13-16$ & 4 \\
III) NMR spectra of IL/HPBI mixtures & $17-20$ & 6 \\
IV) NMR spectra of IL/CMPO mixtures & $21-25$ & 8 \\
V) NMR spectra of IL/TODGA mixtures & $26-29$ & 10 \\
\hline
\end{tabular}




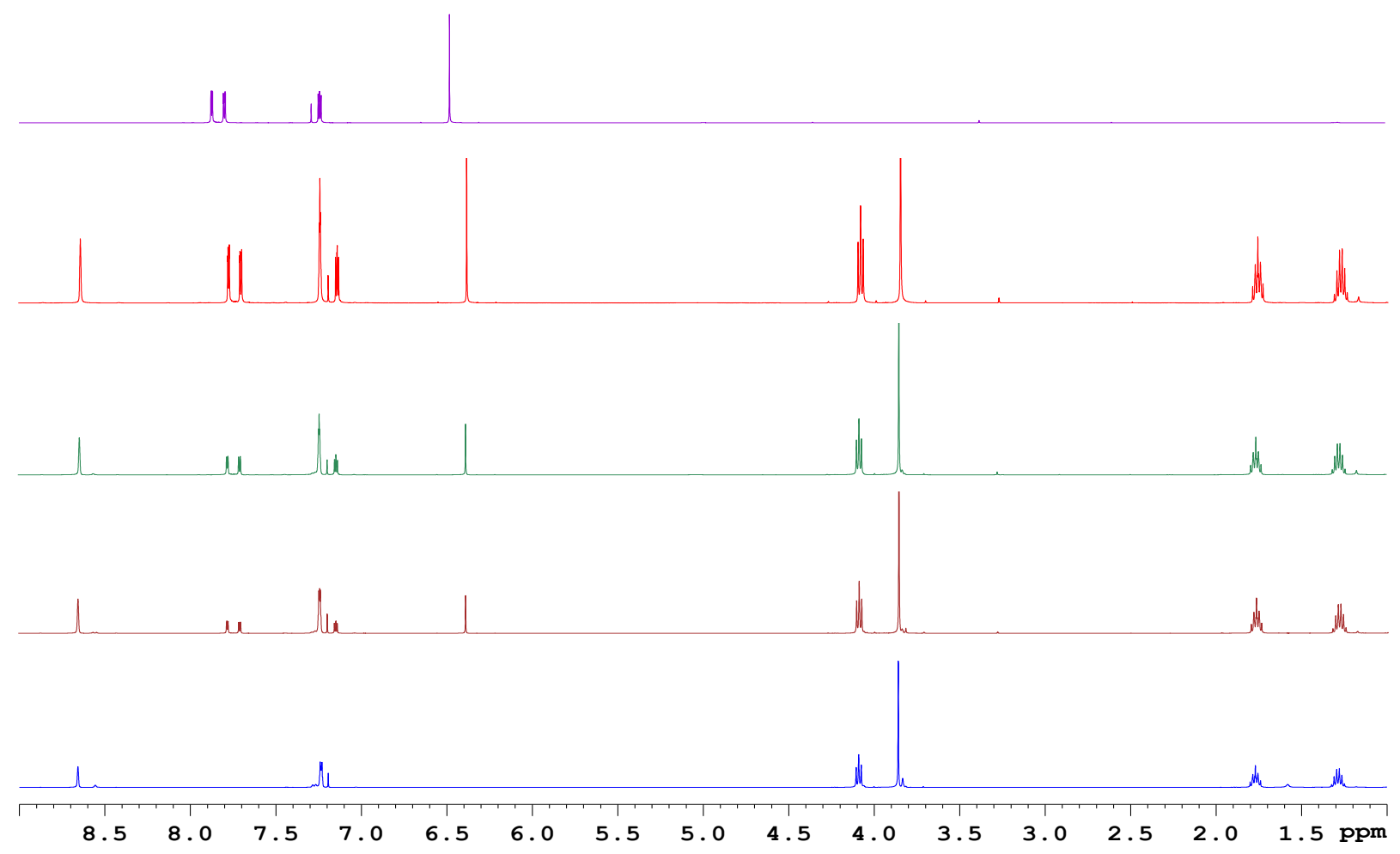

Fig. $9{ }^{1} \mathrm{H}$ NMR spectra of bmimTf $_{2} \mathbf{N}$ (blue), bmimTf 2 N:HTTA 4:1 (brown), bmimTf 2 N:HTTA 2:1 (green), bmimTf 2 N:HTTA 1:1 (red), and HTTA (violet).

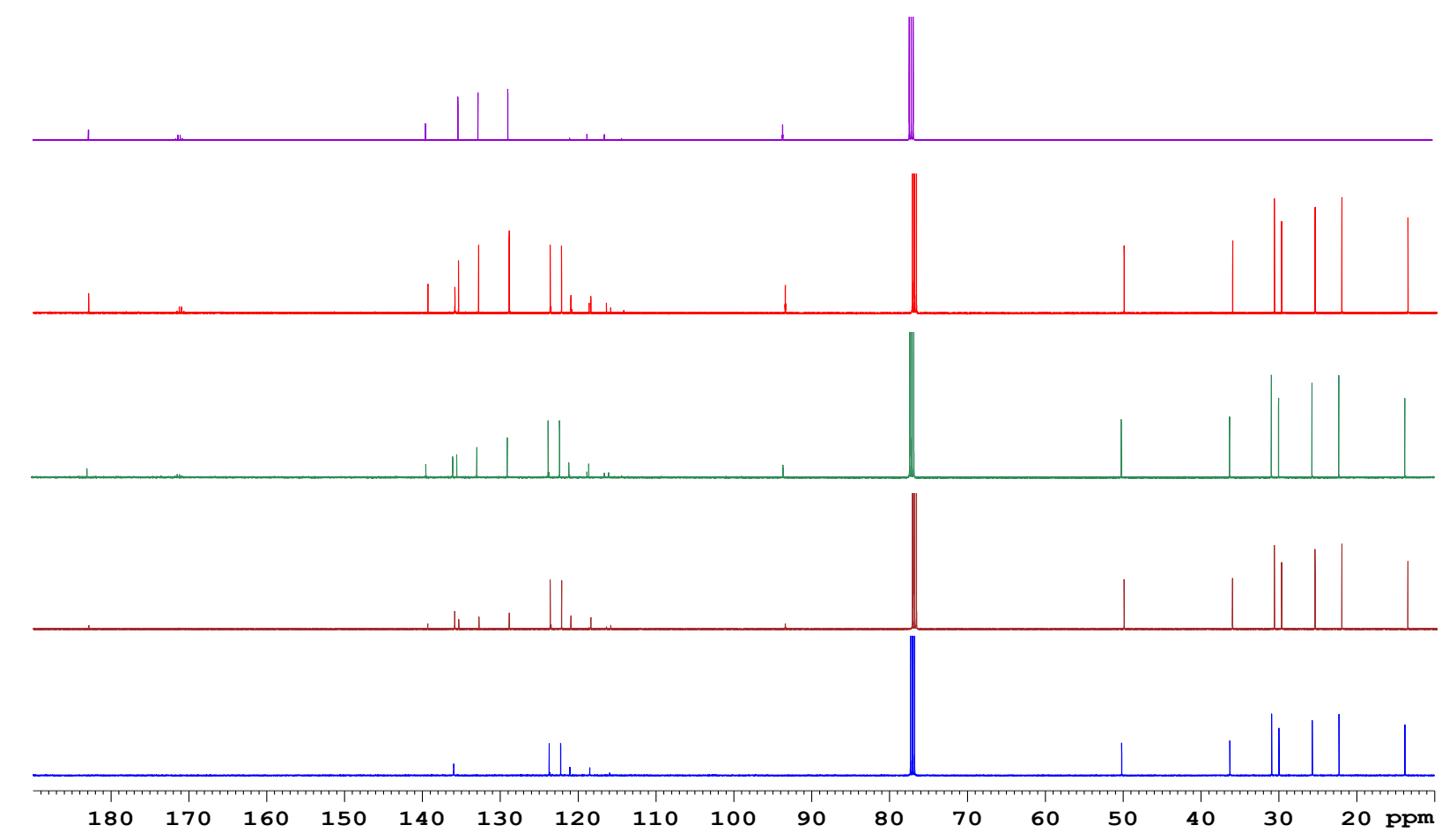

Fig. $10{ }^{13} \mathrm{C}$ NMR spectra of hmimTf $2 \mathbf{N}$ (blue), hmimTf 2 N:HTTA $4: 1$ (brown), hmimTf 2 N:HTTA 2:1 (green), hmimTf 2 N:HTTA 1:1 (red), and HTTA (violet). 


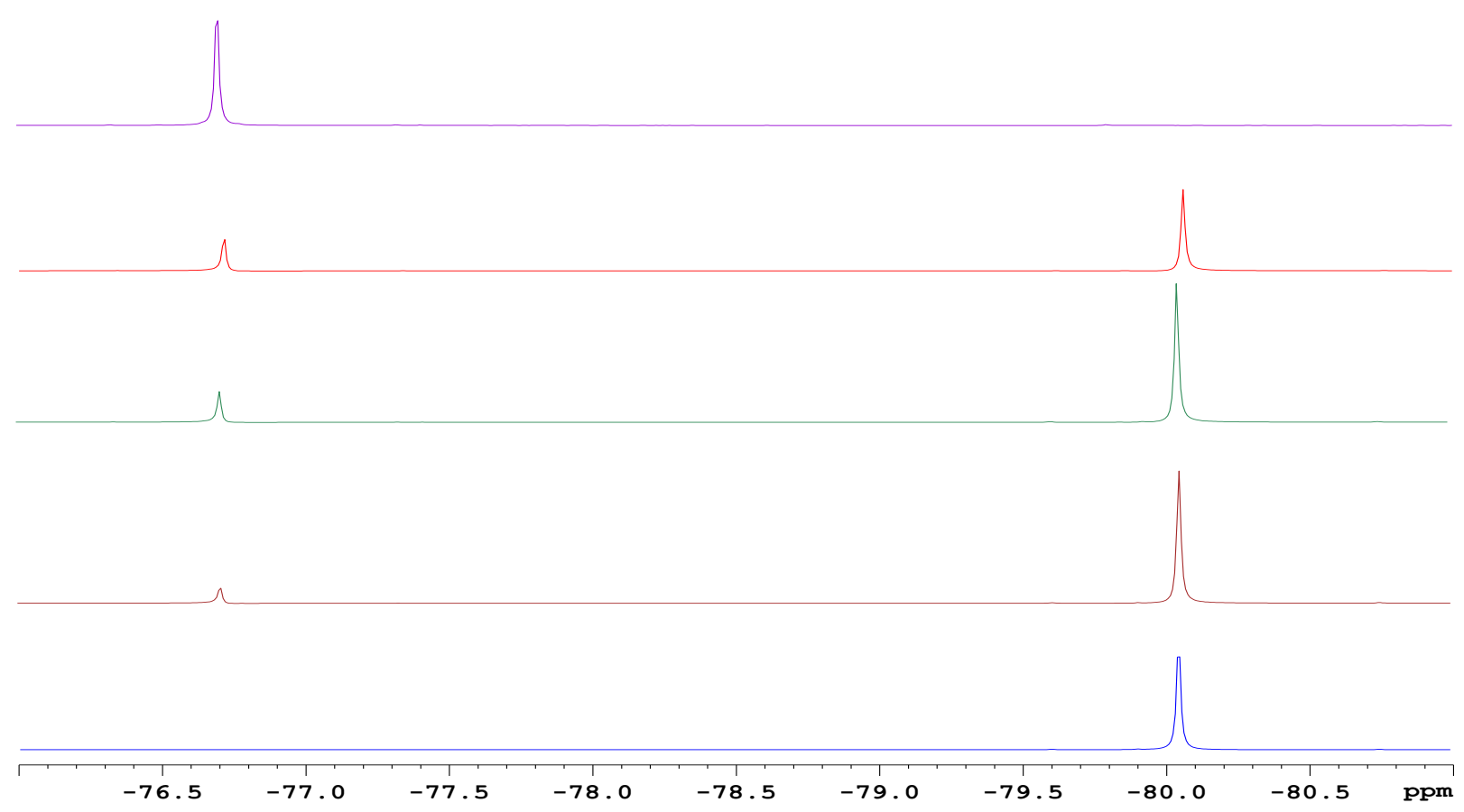

Fig. $11{ }^{19}$ F NMR spectra of omimTf 2 N (blue), omimTf 2 N:HTTA $4: 1$ (brown), omimTf 2 N:HTTA 2:1 (green), omimTf 2 N:HTTA 1:1 (red), and HTTA (violet).



Fig. $12{ }^{1} \mathrm{H}-{ }^{1} \mathrm{H}$ NOESY spectrum of $\operatorname{dmimTf_{2}}$ N:HTTA $1: 1$. 




Fig. $13{ }^{1} \mathrm{H}$ NMR spectra of $\mathbf{h m i m T f _ { 2 }} \mathbf{N}$ (blue), $\operatorname{hmimTf_{2}} \mathbf{N}: H P$ 4:1 (brown), hmimTf $2 \mathbf{N}: H P$ 2:1 (green), hmimTf $2 \mathbf{N}: \mathbf{H P}$ 1:1 (red), and HP (violet).



Fig. $14{ }^{13} \mathrm{C}$ NMR spectra of omimTf $2 \mathbf{N}$ (blue), omimTf 2 N:HP 4:1 (brown), omimTf 2 N:HP 2:1 (green), omimTf $2 \mathbf{N}: \mathbf{H P}$ 1:1 (red), and HP (violet). 


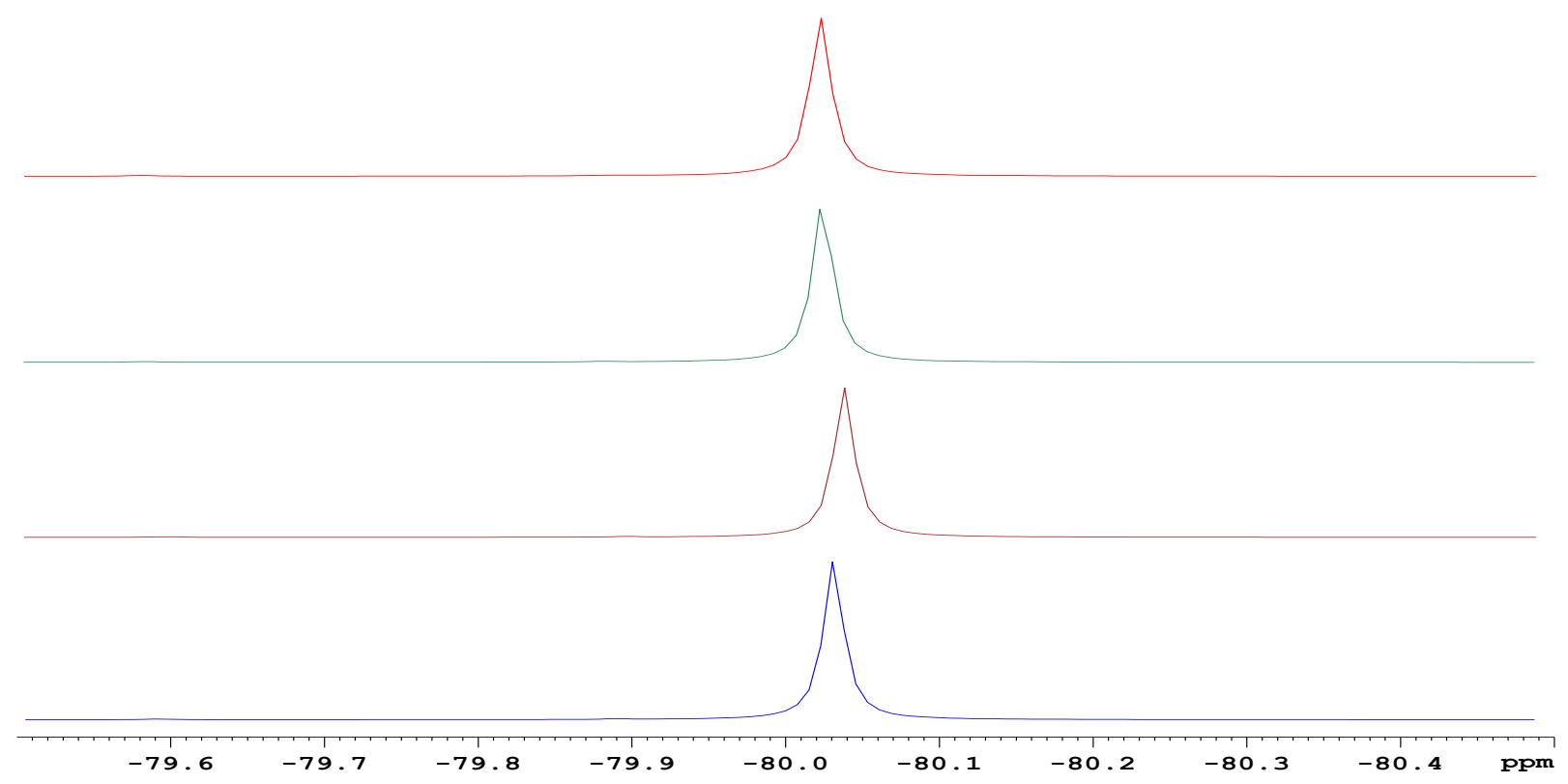

Fig. $15{ }^{19}$ F NMR spectra of $\operatorname{dmimTf}_{2} \mathbf{N}$ (blue), $\operatorname{dmimTf}_{2} \mathbf{N}: H P \quad 4: 1$ (brown), $\operatorname{dmimTf}_{2} \mathbf{N}: H P$ 2:1 (green), and dmimTf 2 N:HP 1:1 (red).



Fig. $16{ }^{1} \mathrm{H}-{ }^{1} \mathrm{H}$ NOESY spectrum of bmimTf $2 \mathbf{N}: \mathbf{H P} 1: 1$. 


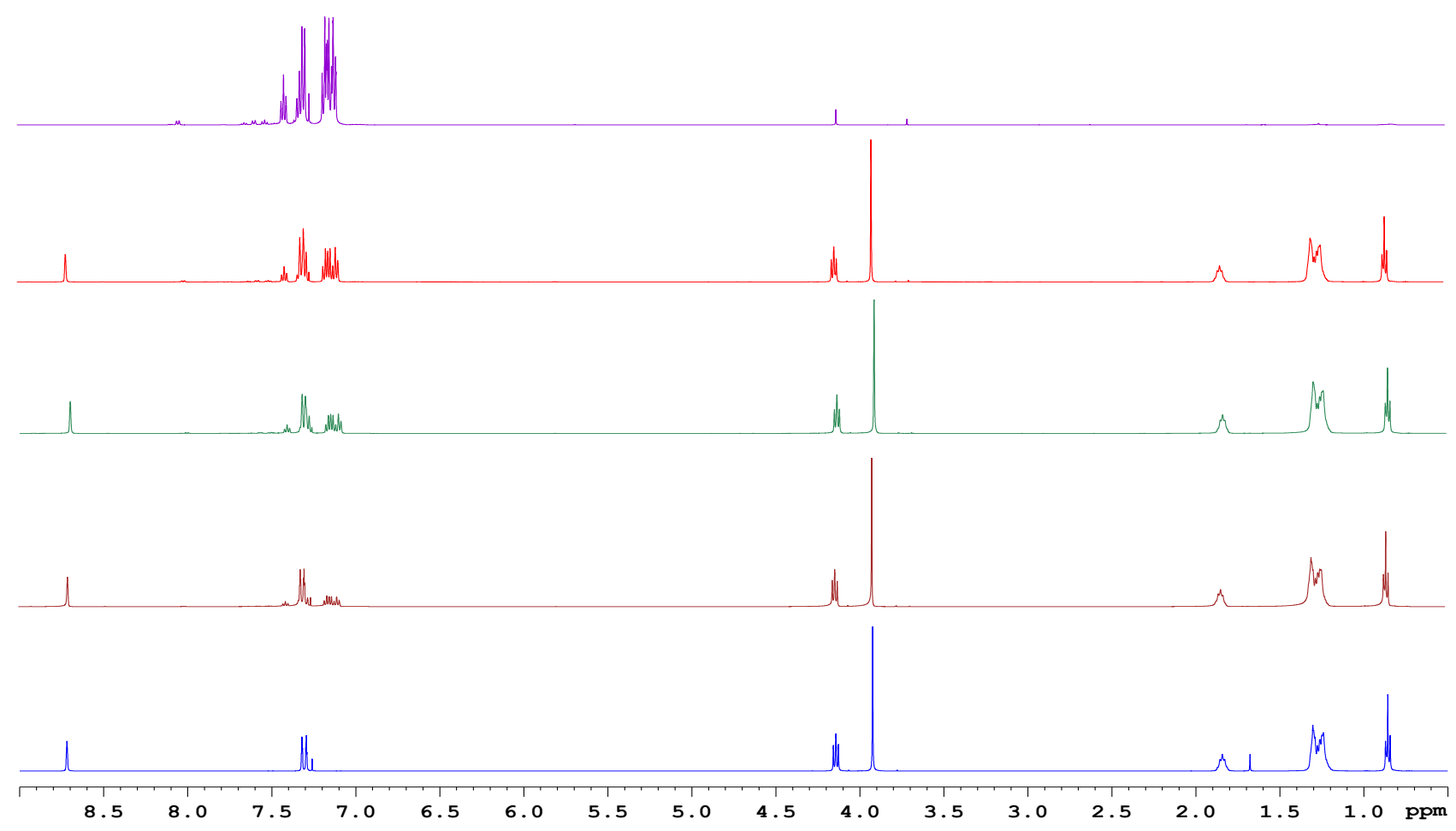

Fig. $17{ }^{1} \mathrm{H}$ NMR spectra of omimTf $2 \mathbf{N}$ (blue), omimTf $\mathbf{o m}_{2} \mathbf{N}:$ HPBI 4:1 (brown), omimTf 2 N:HPBI 2:1 (green), omimTf 2 N:HPBI 1:1 (red), and HPBI (violet).

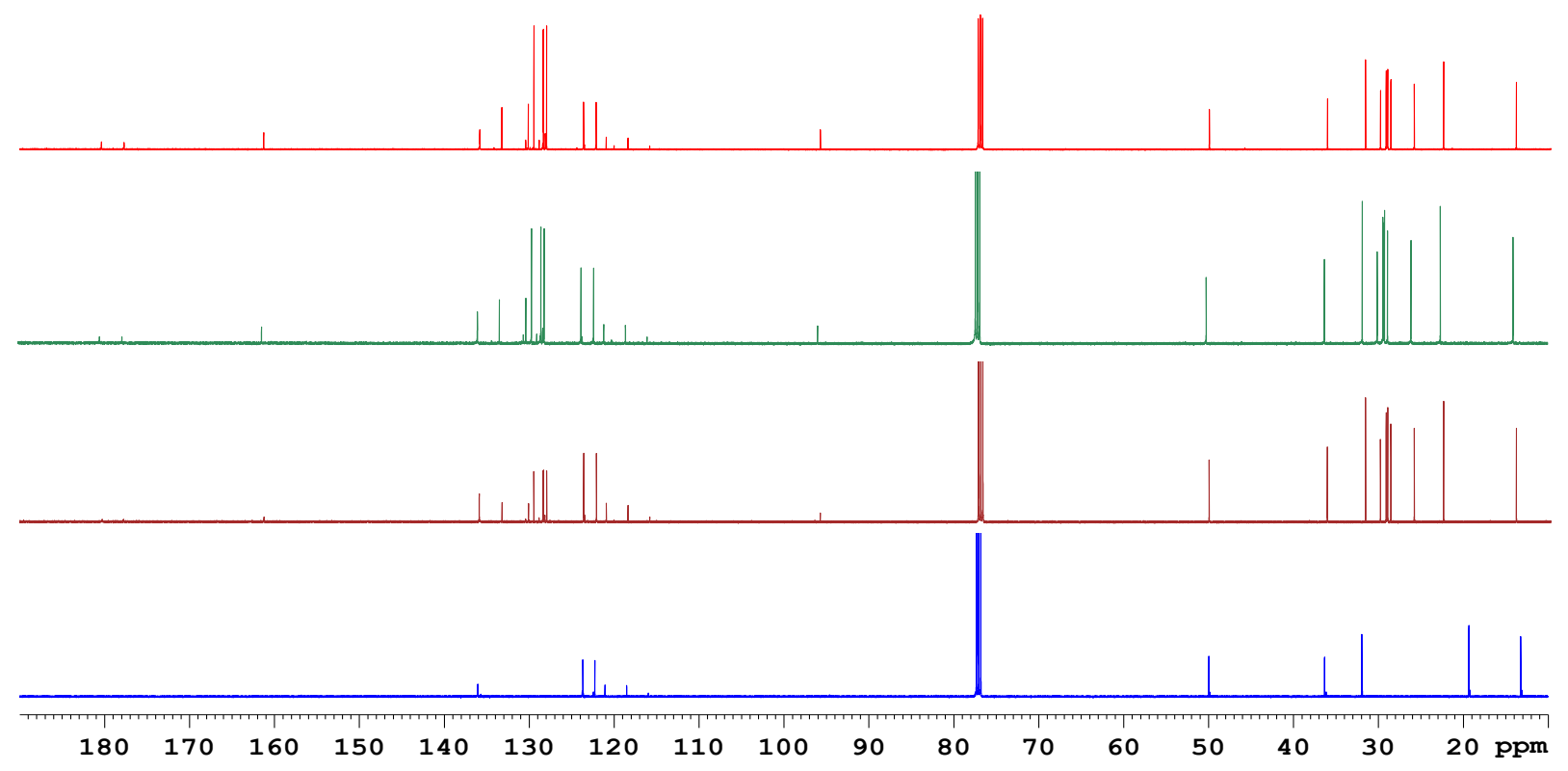

Fig. $18{ }^{13} \mathrm{C}$ NMR spectra of $\operatorname{dmimTf}_{2} \mathbf{N}$ (blue), $\operatorname{dmimTf}_{2} \mathbf{N}: H P B I ~ 4: 1$ (brown), $\operatorname{dmimTf}_{2} \mathbf{N}: H P B I$ 2:1 (green), dmimTf 2 N:HPBI 1:1 (red), and HPBI (violet). 




Fig. $19{ }^{19} \mathrm{~F}$ NMR spectra of $\operatorname{bmimTf}_{2} \mathbf{N}$ (blue), bmimTf $\mathbf{f}_{2} \mathbf{N}:$ HPBI $4: 1$ (brown), bmimTf $\mathbf{b}_{2} \mathbf{N}: \mathbf{H P B I}$ 2:1 (green), and bmimTf 2 N:HPBI 1:1 (red).



Fig. S20 ${ }^{1} \mathrm{H}-{ }^{1} \mathrm{H}$ NOESY spectrum of hmimTf 2 N:HPBI $1: 1$. 
IV) NMR spectra of IL/CMPO mixtures

N W

Whath
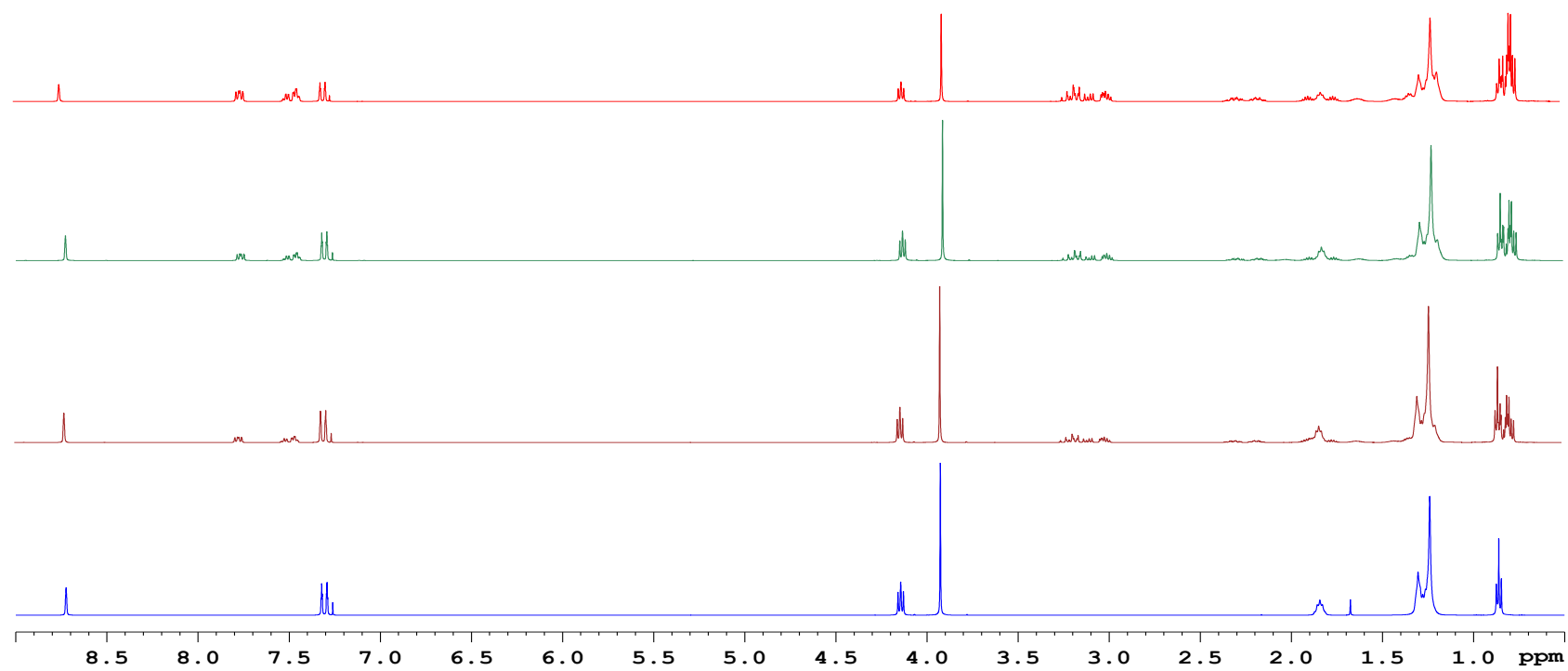

Fig. $21{ }^{1}$ H NMR spectra of $\operatorname{dmimTf}_{2} \mathbf{N}$ (blue), $\operatorname{dmimTf}_{2} \mathbf{N}$ :CMPO 4:1 (brown), $\operatorname{dmimTf}_{2} \mathbf{N}$ :CMPO 2:1 (green), $\operatorname{dmimTf}_{2} \mathbf{N}:$ CMPO 1:1 (red), and CMPO (violet).

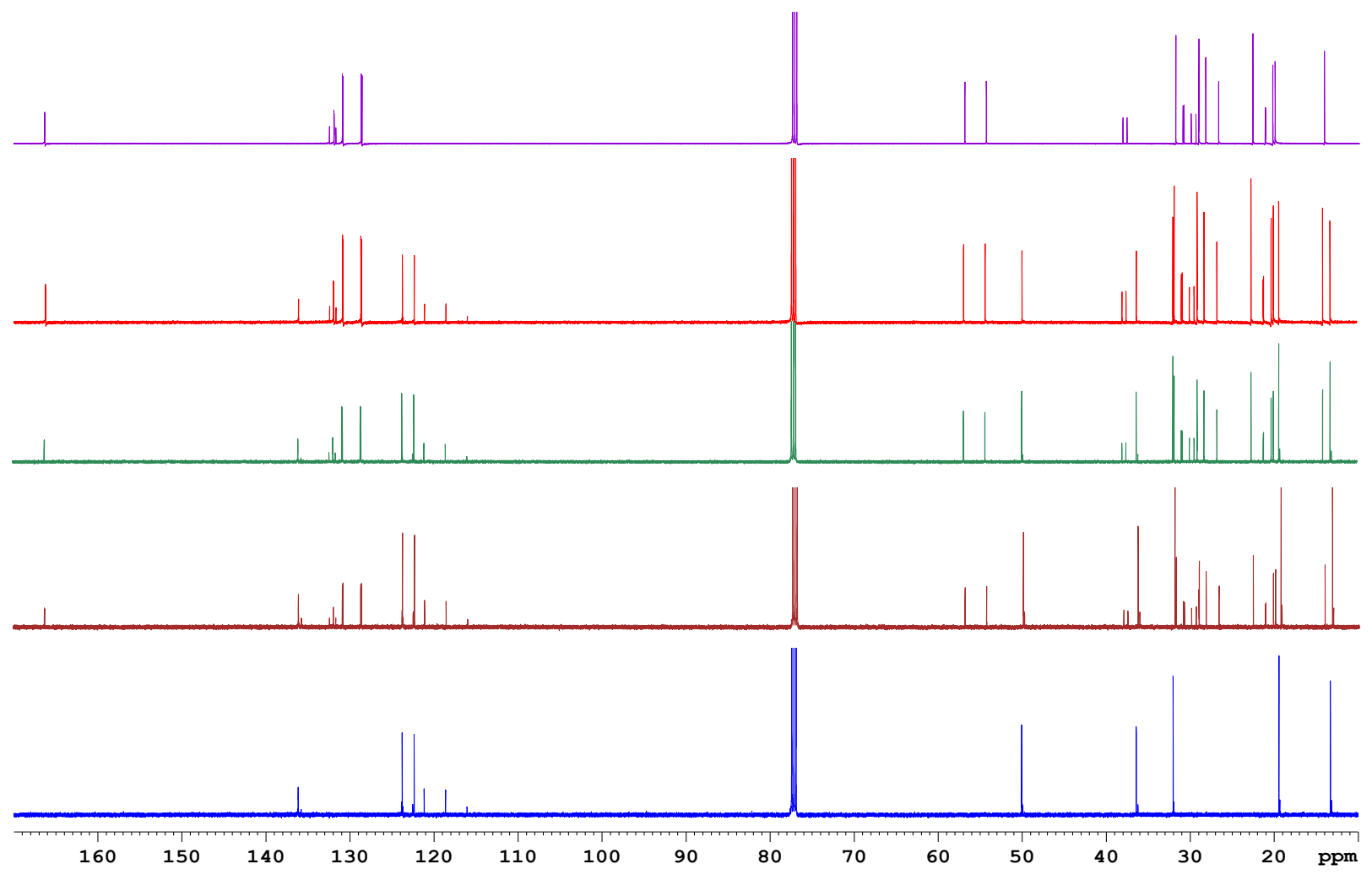

Fig. $22{ }^{13} \mathrm{C}$ NMR spectra of $\operatorname{bmimTf}_{2} \mathbf{N}$ (blue), $\operatorname{bmimTf}_{2} \mathbf{N}: \mathbf{C M P O} \quad 4: 1$ (brown), bmimTf $_{2} \mathbf{N}$ :CMPO 2:1 (green), bmimTf 2 N:CMPO 1:1 (red), and CMPO (violet). 




Fig. $23{ }^{19} \mathrm{~F} \quad \mathrm{NMR}$ spectra of $\operatorname{hmimTf}_{2} \mathbf{N}$ (blue), $\operatorname{hmimTf}_{2} \mathbf{N}: \mathbf{C M P O} 4: 1$ (brown), hmimTf 2 : CMPO 2:1 (green), and hmimTf 2 N:CMPO 1:1 (red).

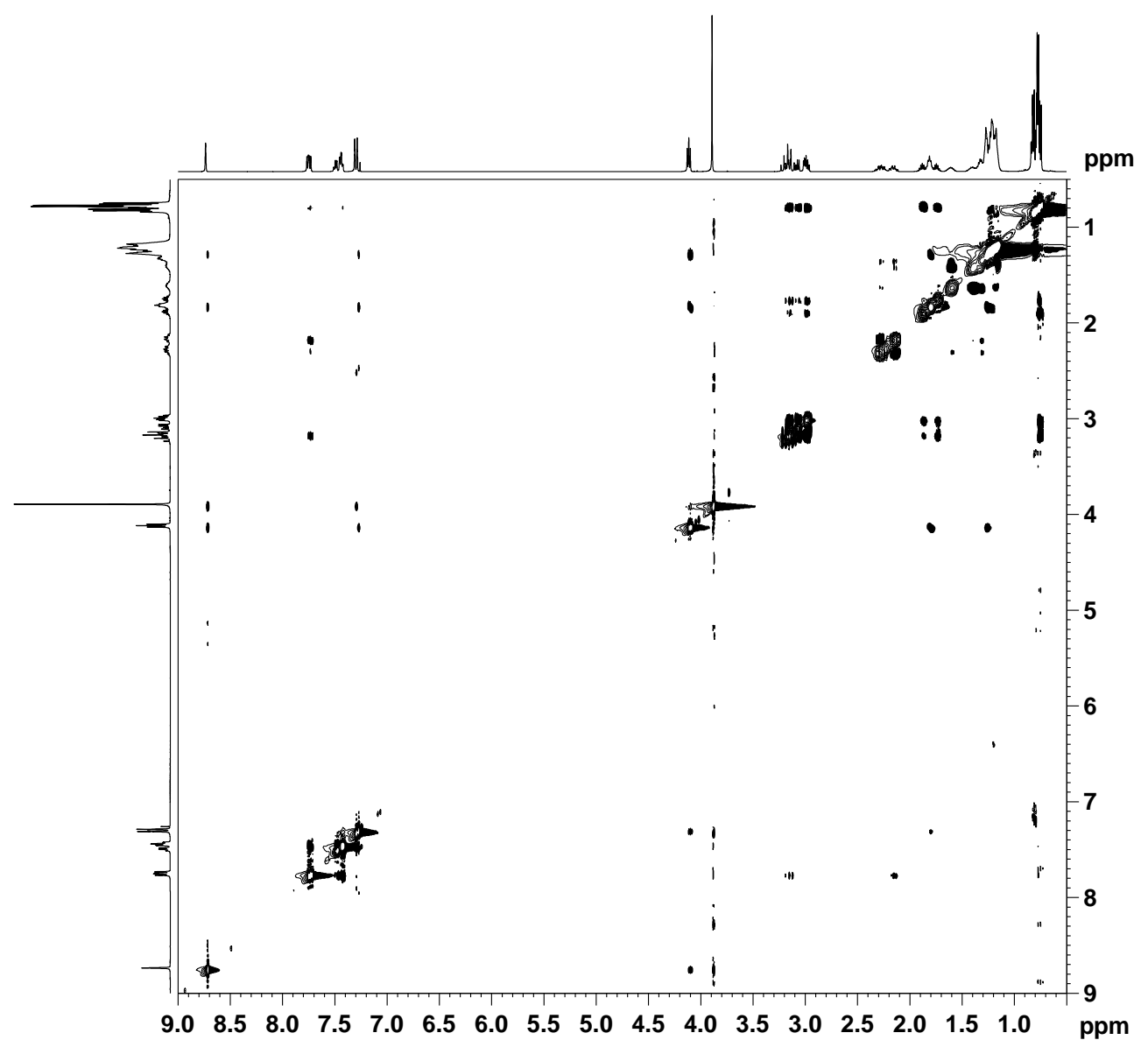

Fig. $24{ }^{1} \mathrm{H}^{-1} \mathrm{H}$ NOESY spectrum of omimTf 2 N:CMPO 1:1. 




Fig. $25{ }^{31} \mathrm{P}$ NMR spectra of CMPO (blue), $\operatorname{dmimTf}_{2} \mathbf{N}: \mathbf{C M P O} 1: 1$ (brown), and $\operatorname{dmimTf}_{2} \mathrm{~N}$ :CMPO 2:1 (green).

V) NMR spectra of IL/TODGA mixtures
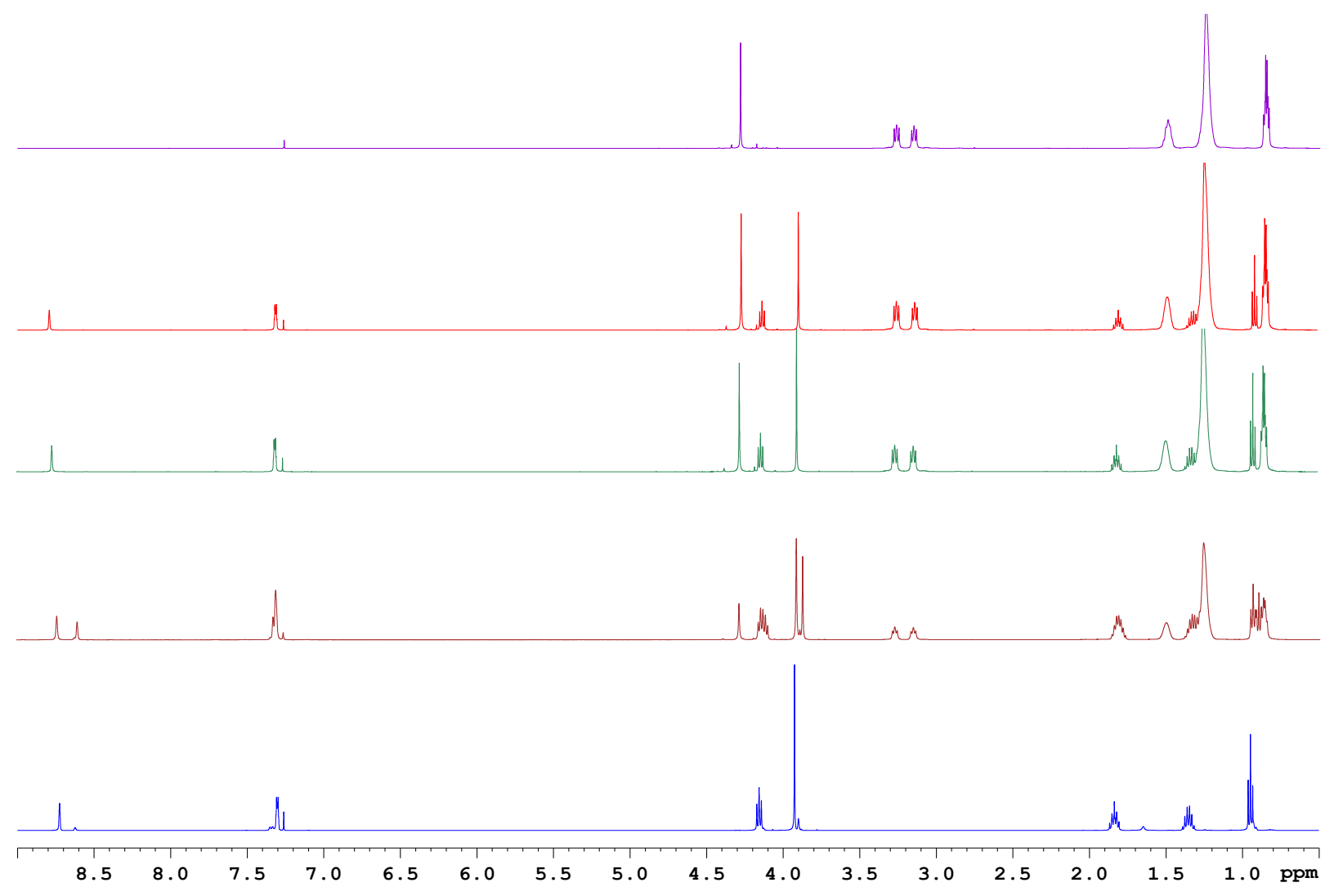

Fig. $26{ }^{1} \mathrm{H}$ NMR spectra of bmimTf $_{2} \mathbf{N}$ (blue), bmimTf $2 \mathbf{N}$ :TODGA 4:1 (brown), bmimTf 2 N:TODGA 2:1 (green), bmimTf 2 N:TODGA 1:1 (red), and TODGA (violet). 


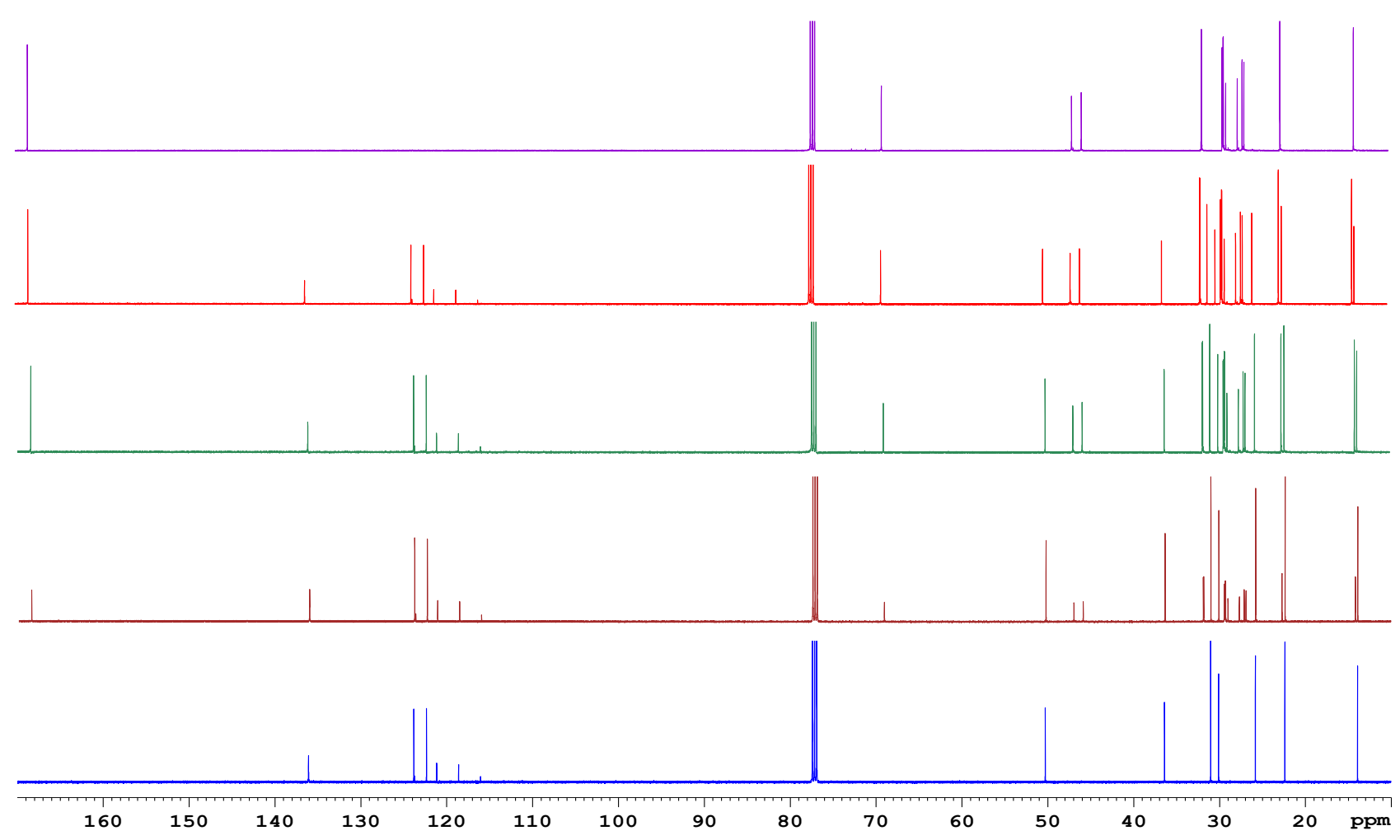

Fig. $27{ }^{13} \mathrm{C}$ NMR spectra of $\operatorname{hmimTf}_{2} \mathbf{N}$ (blue), $\operatorname{hmimTf}_{2} \mathbf{N}$ :TODGA 4:1 (brown), hmimTf 2 :TODGA 2:1 (green), hmimTf 2 N:TODGA 1:1 (red), and TODGA (violet).

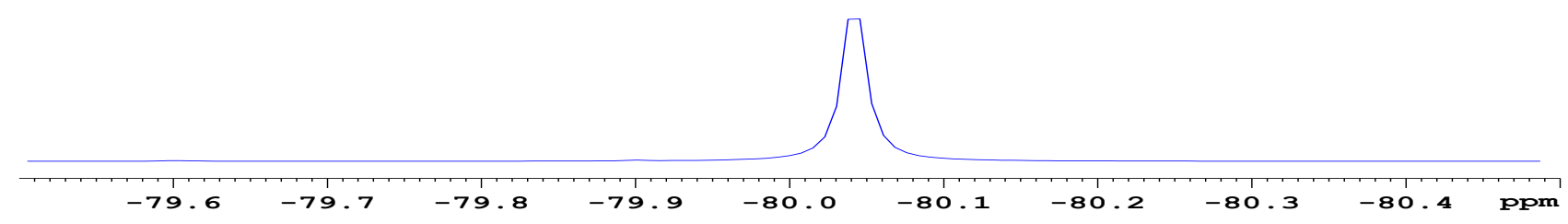

Fig. $28{ }^{19} \mathrm{~F} \quad \mathrm{NMR}$ spectra of $\operatorname{omimTf}_{2} \mathbf{N}$ (blue), omimTf $2 \mathbf{N}$ :TODGA 4:1 (brown), $\operatorname{omimTf}_{2} \mathbf{N}$ :TODGA $2: 1$ (green), and omimTf 2 N:TODGA $1: 1$ (red). 




Fig. $29{ }^{1} \mathrm{H}-{ }^{1} \mathrm{H}$ NOESY spectrum of $\operatorname{dmimTf}_{2} \mathbf{N}$ :TODGA $1: 1$. 
Ali Ouadi

ali.ouadi@iphc.cnrs.fr

CNRS, IPHC-Strasburg, Radiochemistry, France

Magdalena Bendova

bendova@icpf.cas.cz

E. Hala Laboratory of Separation Processes

Institute of Chemical Process Fundamentals of the ASCR, Czech Republic

Mara Freire

maragfreire@ua.pt

University of Aveiro, CICECO

Milen Bogdanov

mbogdanov@chem.uni-sofia.bg

Sofia University, Faculty of Chemistry and Pharmacy 